ex Instituto Archaeologico Universitatis de Rolando Eötvös nominatae

C

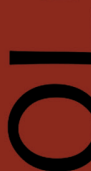

ப

$\varangle$

工

$\cup$

ه

$<$

in

ㄴ
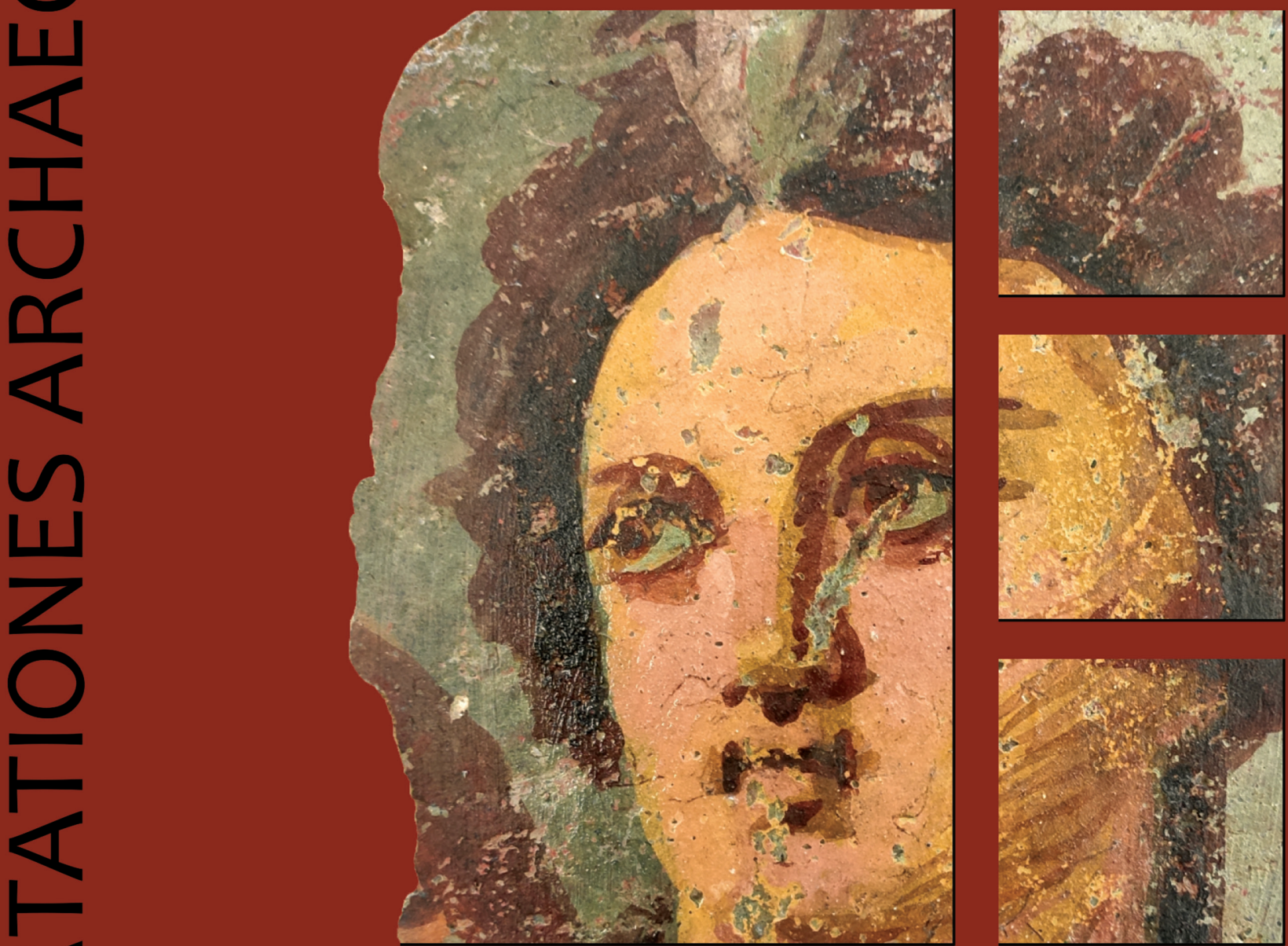

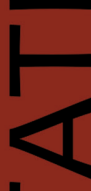

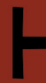

ח

Ш

un

n

0
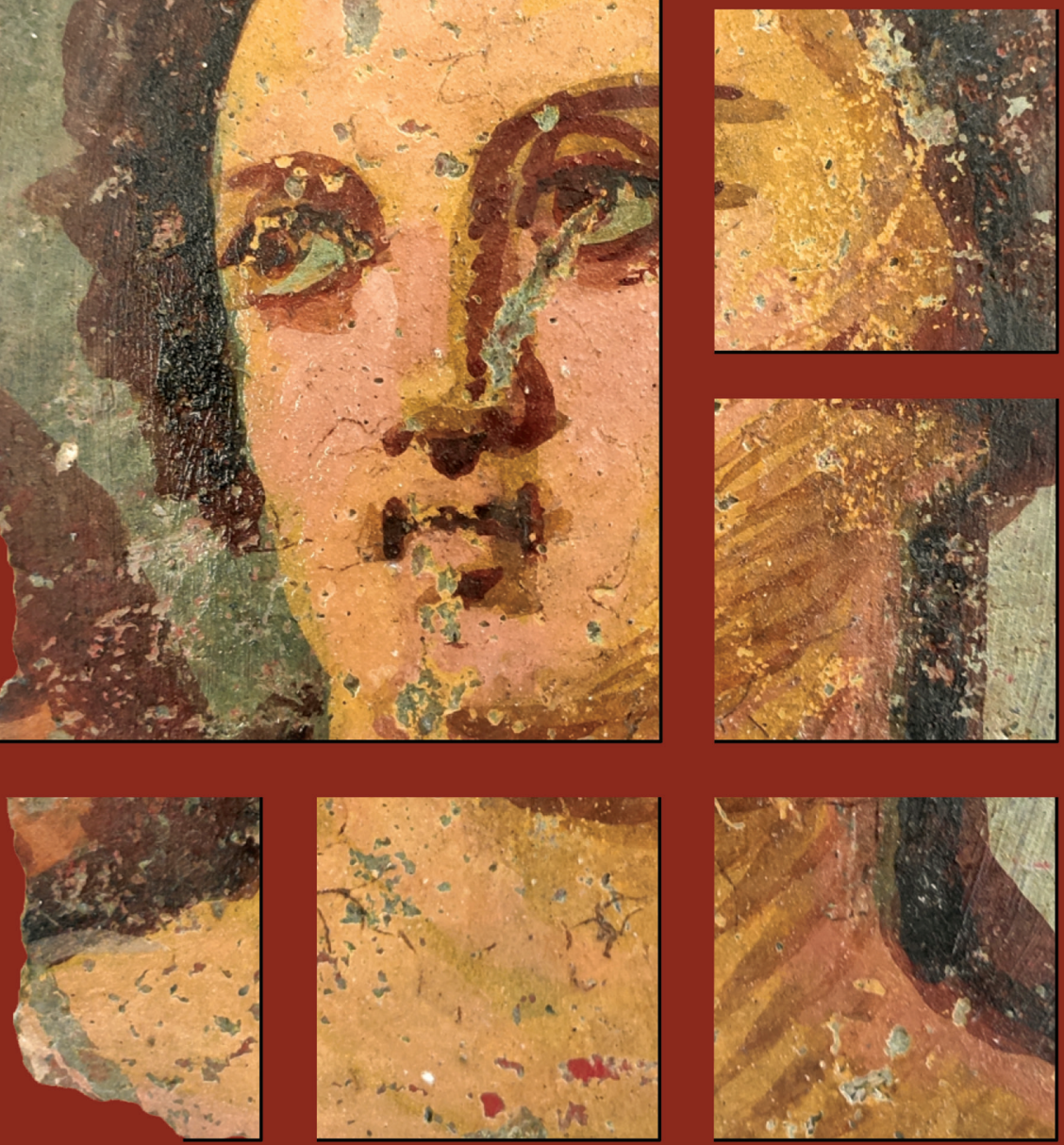

Serp 30 No. 8. 2020 


\section{Dissertationes Archaeologicae ex Instituto Archaeologico}

Universitatis de Rolando Eötvös nominatae Ser. 3. No. 8.

Budapest 2020 
Dissertationes Archaeologicae ex Instituto Archaeologico Universitatis de Rolando Eötvös nominatae Ser. 3. No. 8.

Editor-in-chief:

DÁvid Bartus

Editorial board:

LÁsZló BARTOSIEWICZ

LÁsZLÓ BORHY

ZOLTÁN CZAJLIK

IsTVÁN FELD

GÁBOR KALLA

PÁL RACZKY

MiKLÓS SZABÓ

Tivadar Vida

Technical editor:

Gábor VÁczi

Proofreading:

Szilvia BARTUS-SzÖLLŐsI

Zsófia KondÉ

Márton SZILÁGYI

Aviable online at http://ojs.elte.hu/dissarch

Contact: dissarch@btk.elte.hu

ISSN 2064-4574

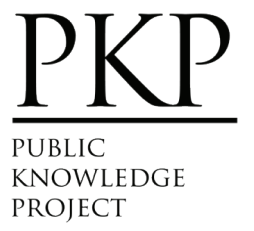

๑ ELTE Eötvös Loránd University, Institute of Archaeological Sciences

Layout and cover design: Gábor Váczi

Budapest 2020 


\section{CONTENTS}

\section{ARTICLES}

Maciej WAWRZCZAK - Zuzana KASENČÁKovÁ

Stará L'ubovña - Lesopark. Late Palaeolithic site and the problems associated with raw material mining

Attila PÉNTEK - Norbert FARAgó

Chipped stone assemblages from Schleswig-Holstein (North Germany) in the collection of the Institute of Archaeological Sciences - ELTE Eötvös Loránd University

Bence Soós 49

Middle Iron Age Cemetery from Alsónyék, Hungary

Tamás Szeniczey - Tamás Hajdu 107

Appendix - Results of the analysis of the Early Iron Age human remains unearthed at Alsónyék, Hungary

Lajos JuHÁsz - József Géza Kiss

Bound in bronze - a Roman bronze statuette of a barbarian prisoner

Csilla SÁRó

The fibula production of Brigetio: clay moulds

\section{Field Reports}

András Füzesi - Knut Rassmann - Eszter BÁnffy - Hajo Hoehler-Brockmann -

Gábor Kalla - Nóra Szabó - Márton SzIlágyi - Pál Raczky

Test excavation of the "pseudo-ditch" system of the Late Neolithic settlement complex at Öcsöd-Kováshalom on the Great Hungarian Plain

Gábor VÁczi - László RupNIK - Zoltán CZAJLIK - Gábor MEsterházy Bettina BitTner - Kristóf FÜlöP - Denisa M. LÖNHARdT - Nóra Szabó

The results of a non-destructive site exploration and a rescue excavation at the site of Pusztaszabolcs-Dohányos völgy északi part

Dávid BArtus - László Borhy - Szilvia JohÁczi - Emese SzÁmadó 181

Excavations in the legionary fortress of Brigetio in 2019 
Dávid BArtus - László Borhy - Emese SzÁmadó - Lajos Juhász - Bence Simon -

Ferenc Barna - Anita Benes - Szilvia Joháczi - Rita Olasz - Melinda Szabó

Excavations in Brigetio in 2020

\section{Thesis Abstracts}

Anett OszTÁs

The settlement history of Alsónyék-Bátaszék.

Complex analysis of its buildings in the context of the Lengyel culture

Csilla SzÁRAz

The region of the Zala and Mura Rivers (Zala County) in the Late Bronze Age.

Late Tumulus and Urnfield period

Ágnes KIRÁly

Human remains unearthed in settlement context from the Late Bronze Age -

Early Iron Age (Reinecke BD-HaB3) Northeastern Hungary

Gergely BóKA

Transformation of settlement history in the Körös Region in the period between the Late Bronze Age and the end of Iron Age

Gabriella G. DeLbó

Pottery production of the settlement complex of Brigetio

Adrienn Katalin BLAY

Die Beziehungen zwischen dem Karpatenbecken und dem Mediterraneum

von der II. Hälfte des 6. bis zum 8. Jahrhundert n. Chr. anhand Schmuckstücken

und Kleidungszubehör

Levente SAMU

293

Die mediterranen Kontakte des Karpatenbeckens in der Früh- und Mittel-

awarenzeit im Licht der Männerkleidung. Gürtelschnallen und Gürtelgarnituren

\section{REviEWS}

Gábor MESTERHÁZY

Czajlik, Z. - Črešnar, M. - Doneus, M. - Fera, M. - Hellmith Kramberger, A. Mele, M. (eds): Researching Archaelogical Landscapes Across Borders - Strategies,

Methods and Decisions for the 21th Century. Graz-Budapest, 2019. 


\title{
The fibula production of Brigetio: clay moulds
}

\author{
Csilla SÁró \\ MTA - ELTE Research Group \\ for Interdisciplinary Archaeology \\ sarocsilla@gmail.com
}

\begin{abstract}
Fibula production can be proven in the case of several Pannonian bronze workshops and among these, Brigetio as well. Similar fibula variations from a close territory can refer to the production in a certain area but the archaeological finds which belong to the manufacturing process are more trustworthy evidences. Regarding the fibulae produced in Brigetio, I. Kovrig, E. Patek, E. B. Bónis, K. Szabó, M. Merczi and N. Sey have already published some more or less detailed parts of their research. During a research project, the author reinvestigated several archaeological finds which can be related to the fibula production of Brigetio. The main aim of this paper is the definition of the fibula variants and the examination of their regional distribution. Moreover, the dating of the locally manufactured fibula variants can be helpful to define the production period of the workshops.
\end{abstract}

\section{Introduction}

The existence of the bronze workshops of Brigetio is well known for a long time. ${ }^{1}$ Recently, $\mathrm{N}$. Sey concluded a detailed research work. According to her $\mathrm{PhD}$ thesis, bronze workshops have been functioning at 28 archaeological sites in Pannonia, with Brigetio among them. ${ }^{2}$ Based on the known archaeological finds, several articles were produced in the workshops of Brigetio. Bronze statuettes, vessels, other personal articles, dress accessories, fibulae and lead votives were manufactured there. ${ }^{3}$ The localization of the bronze workshops is difficult because most of the finds which belong to the manufacturing process came to light without an exact location documented. Based on the known data, bronze workshops were both functioning in the territory of the legionary fortress, the canabae and the civilian town. ${ }^{4}$

Particular evidences for the fibula production are semi-finished fibulae, failed castings, moulds, models of fibulae and ingots. Apart from the ingots, types/subtypes/variants/variations of the fibulae can be defined according to the main characteristics.

1 This paper is part of the "Brigetiói fibulák elemezése hagyományos régészeti szemléletü és müszeres vizsgálati módszerekkel” research project, supported by the ÚNKP-19-3 New National Excellence Program of the Ministry of Human Capacities. I would like to express my gratitude to László Borhy MHAS (ELTE BTK), dr. Richárd Schmidtmayer, Mária Kempf (KDM), Emese Számadó (KGyM), Zsolt Mráv, Erika Kovács, József Puskás (HNM), Julianna Kisné Cseh and Gabriella A. Pál (TBM) for the reserach opportunity and their help.

2 The archaeological sites are the following: Albertfalva, Alsórajk-Kastélydomb, Aparhant, Aquincum, Arrabona, Badacsonytomaj-Paprét, Baláca, Brigetio, Carnuntum, Gorsium, Győr-Ménfőcsanak, Gyulafirátót-Pogánytelek, Intercisa, Keszthely-Fenékpuszta, Kulcs, Lengyel, Lussonium, Mursella, Nagyberki-Szalacska, Neviodunum, Páty-Malomdűlő, Salla, Savaria, Scarbantia, Siscia, Solva, Szakály-Rétiföldek, Tokod-Erzsébetakna (SEY 2013a, 35-85; SEY 2013b, 252. Fig. 1.).

3 Bartus 2011, 18-26; Sey 2013a, 46-58, 166-178; Bartus 2014a; Bartus 2014b; Bartus 2015, 14-15, 22, 125-126, 128; SEY 2015, 225-228; SEY 2018, 227.

4 Sey 2013a, 46-58, 166-178; BArtus et al. 2014, 439; BArtus 2015, 22, 128; BArtus et al. 2015b, 247-248; SEY 2015; BARTus et al. 2018, 66, 76; SEY 2018, 225-227. 
According to recent research, fibulae were certainly manufactured at 13 archaeological sites in Pannonia. ${ }^{5}$ Based on the earlier data ${ }^{6}$ and some new information, ${ }^{7}$ strongly profiled fibulae, pannonian trumpet fibulae, knee fibulae, crossbow fibulae, plate fibulae and probably enamelled fibulae were manufactured in the workshops of Brigetio. In this paper, fibula types represented by the casting moulds will be introduced in detail.

\section{Moulds from Brigetio}

Several moulds were found in the territory of Brigetio, ${ }^{8}$ six of these were possibly used for fibula production. All of the moulds are made of clay. Half of the moulds (Cat. 1-3) came to light from the territory of Brigetio without an exact location, while the others were found in the area of the civil town (Cat. 4) and the military town (Cat. 5-6).

In most cases, it is hard to establish what kind of fibula was made in a certain mould. The negative of the fibula is mostly preserved in a poor condition, or no typical detail of the fibula is visible on the fragmented mould for the unaided eye. During my research I tested a new opportunity and made some investigations with a 3D scanner (Artec Space Spider). ${ }^{9}$ The scanned pictures were used for modeling done by András Bödőcs, senior research fellow of the Eötvös Loránd University Faculty of Humanities, Institute of Archaeological Sciences. Thus the positive pictures of the fibulae can be interpreted precisely. Unfortunately, the three intact pieces without exact location provide the most valuable information about the types while the other three pieces could not be examined in detail. In the following part of the paper, the fibula types will be discussed.

\section{The fibula types}

Cat. 1 is one half of a two-piece clay mould, which was used for casting two fibulae at a time. The negative shapes of the fibulae are quite visible and the model can unquestionably prove the exact type, which is the Almgren $84=$ Merczi 2014/3. ${ }^{10}$

Previously, the types of the fibulae were correctly identified by several researchers as strongly profiled fibulae. ${ }^{11}$ I. Kovrig tried to give a more precise definition and identified their type of her T. VI. 54 based on the wide catchplate of the fibulae, ${ }^{12}$ while in the recent past M. Merczi defined them as Merczi 2014/3. ${ }^{13}$ Based on the 3D scanned pictures and the positive models,

5 Aparhant, Aquincum, Arrabona, Badacsonytomaj-Paprét, Brigetio, Carnuntum, Győr-Ménfősanak, Mursella, Salla, Savaria, Siscia, Szakály-Rétiföldek, Tokod-Erzsébetakna (SEy 2013a, 38, 40-41, 43-44, 49-50, 54-57, 60-62, 67, 70, 73-74, 78-80).

6 Kovrig 1937, 90-91; PAtek 1942, 62; B. Bónis 1986, 301; Szabó 1990, 130-131, 148-149; Berecz 2008, 182-183; Sey 2013a, 49-50, 54-57; MerCZi 2014, 18; Sey 2015, 226-230.

7 During the research project the author examined archaeological finds in the collection of the Komáromi Klapka György Museum (Komárom), the Kuny Domokos Museum (Tata) and the Hungarian National Museum (Budapest). The summarized information was presented at the conference of the Fiatal Római Koros Régészek 14. Konferenciája (FIROKONF) - VIROKONF and will be published in the conference volume.

8 Sey 2013a, Kat. 53-55, Kat. 73-75; SEy 2015, Cat. 11-13; Sey 2018, Cat. 111-117, Cat. 134.

9 I wish to express my gratitude to Szilvia Joháczi (PhD student, ELTE Eötvös Loránd University - Institute of Archaeological Sciences) for her help with the scanning.

10 Almgren 1923, Taf. IV. 84; Merczi 2014, 17-18.

11 B. Bónis 1986, 301; Sey 2013a, 49, Kat. 53.

12 Kovrig 1937, 16.

13 MerCZI 2014, 18. 
this interpretation can be reinforced. Several main characteristics of the Almgren $84=$ Merczi 2014/3 fibulae can be seen in these pictures, which are the following (Fig. 1):

- the fibulae do not have a headplate,

- in front view, the bow has a triangular shape,

- the dividing knob only extends to the top side,

- the cross-section of the bow is triangular in front of the dividing knob and also behind it,

- the bow ends in a knob,

- the broad catchplate is rectangular.

A further detail can be observed in the negative picture: it can be seen inside the mould that the hook of the upper fibula was pierced. Two-piece fibulae have a pierced hook and this hole was normally created as one of the final steps during the manufacturing process so this detail suggests that a semi-finished fibula was used to make this mould.
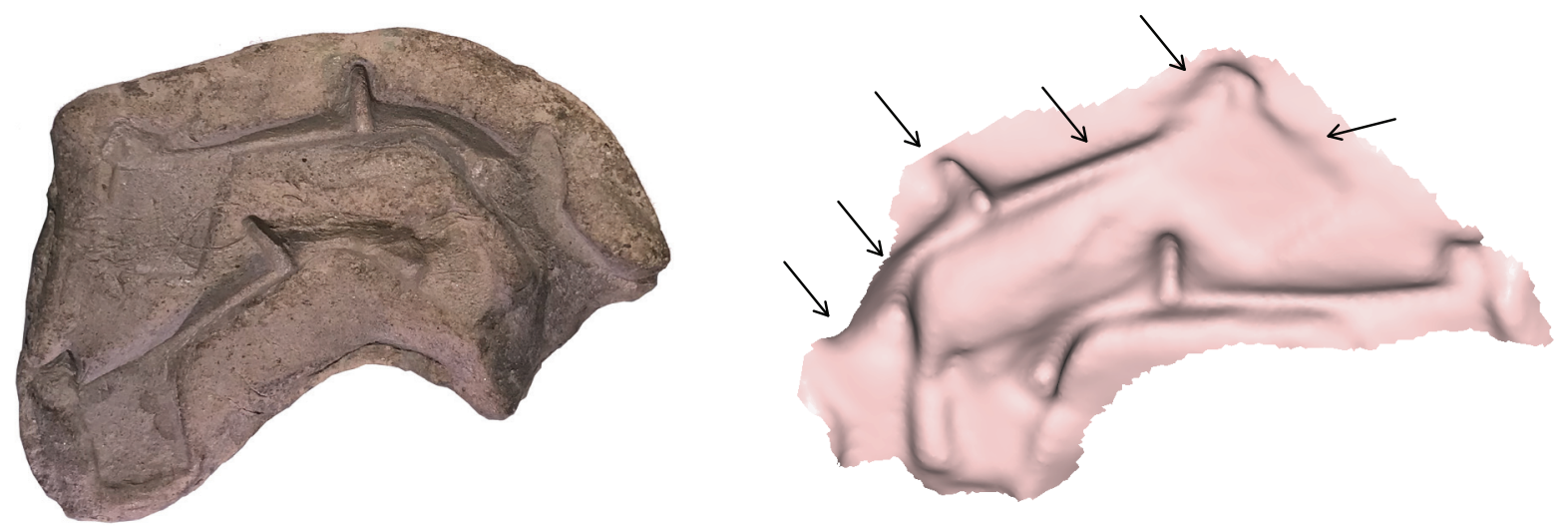

Fig. 1. Cat. 1. clay mould and the positive model (made by A. Bödőcs).

The Almgren $84=$ Merczi 2014/3 is a popular variant in Brigetio and in Komárom-Esztergom County (App. 1) and a great number of these fibulae are also known from other territories of Pannonia and Dacia. Although in smaller numbers, they can be found in Noricum, Moesia, Dalmatia and in the Northern Barbaricum as well. ${ }^{14}$ This variant can be dated to the 2 nd century and possibly the beginning of the 3rd century AD. ${ }^{15}$

Cat. 2 is also one half of a two-piece clay mould. According to the imprints, two fibulae could have been cast with this mould at the same time. Previously, certain researchers managed to correctly define their type as knee fibulae. ${ }^{16}$ The variant of these fibulae can be reinvestigated

14 It is summarized by M. Merczi (Merczi 2014, 18-19). Further pieces from Pannonia: Bruckneudorf (FArkA 1977, 394, Abb. 250-251), Carnuntum (Farka - Jungwirth 1984, 296, Abb. 503; Farka 1988, 313-314, Abb. 676, Abb. 705; Farka - Jungwirth 1989, 232, Abb. 1140; Krenn-Leeb - Jandrasits 1994, 579, Abb. 823), Deutsch Jahrndorf (FArKa - Stelzer 1983, 275, Abb. 404), Edelstal (Grausam - NowaK 1988, 293, Abb. 340), Hollern (Grausam et al. 1992a, 493, Abb. 787), Jois (MAtouschek 1980, 485, Abb. 460), Kaisersteinbruch (FARKA - Winter 1980, 485, Abb. 465), Mannersdorf am Leithagebirge (FArka - Melzer 1979a, 454, Abb. 521), Neckenmarkt (LACKNer 1999, 822, Abb. 445), Pöttsching (FArka - Matouschek 1987, 232, Abb. 399), Sankt Margarethen (Matouschek 1990, 229, Abb. 787), Schützen am Gebirge (Seyfried 1983, 277, Abb. 426), Sommerein (FArka - Melzer 1979b, 464, Abb. 547), Strebersdorf (FArKa - Kropf 1986, 278, Abb. 540), Zurndorf (Nowak 1988, 302, Abb. 466; Grausam et al. 1992b, 474, Abb. 609).

15 Stundner 2006, 140; MercZi 2012, 487; MercZi 2014, 20.

16 Kovrig 1937, 20-21, 90; PAtek 1942, 62, 30. footnote; Sey 2013a, 49. 
in the light of the new data. In the scanned picture and on the positive models several details help the definition (Fig. 2):

- based on its arc, the headplate was possibly semicircular,

- the headplate joins the bow with a small, semicircular step,

- the bow has a semicircular cross-section,

- the bow is "S"-shaped in profile,

- the catchplate is narrow and rectangular, its bent end is possibly thickened,

- only the end of the bow cannot be examined.

According to the information, these fibulae belong to M. Merczi's B/2 variant. ${ }^{17}$ The end of the bow would help a more accurate definition, but unfortunately it is missing. Based on the bow's end, fibulae with these characteristics can belong to variants I-E3/F3/G3 in K. Berecz's typology (1987).${ }^{18}$ Merczi B/2 fibulae can be found in the whole territory of Pannonia. ${ }^{19}$ Based on the known pieces (App. 2), it was also very popular in Brigetio and in the territory of today's Komárom-Esztergom County. This variant was probably used from the Hadrian Age to the beginning of the $3 \mathrm{rd}$ century $\mathrm{AD}^{20}$
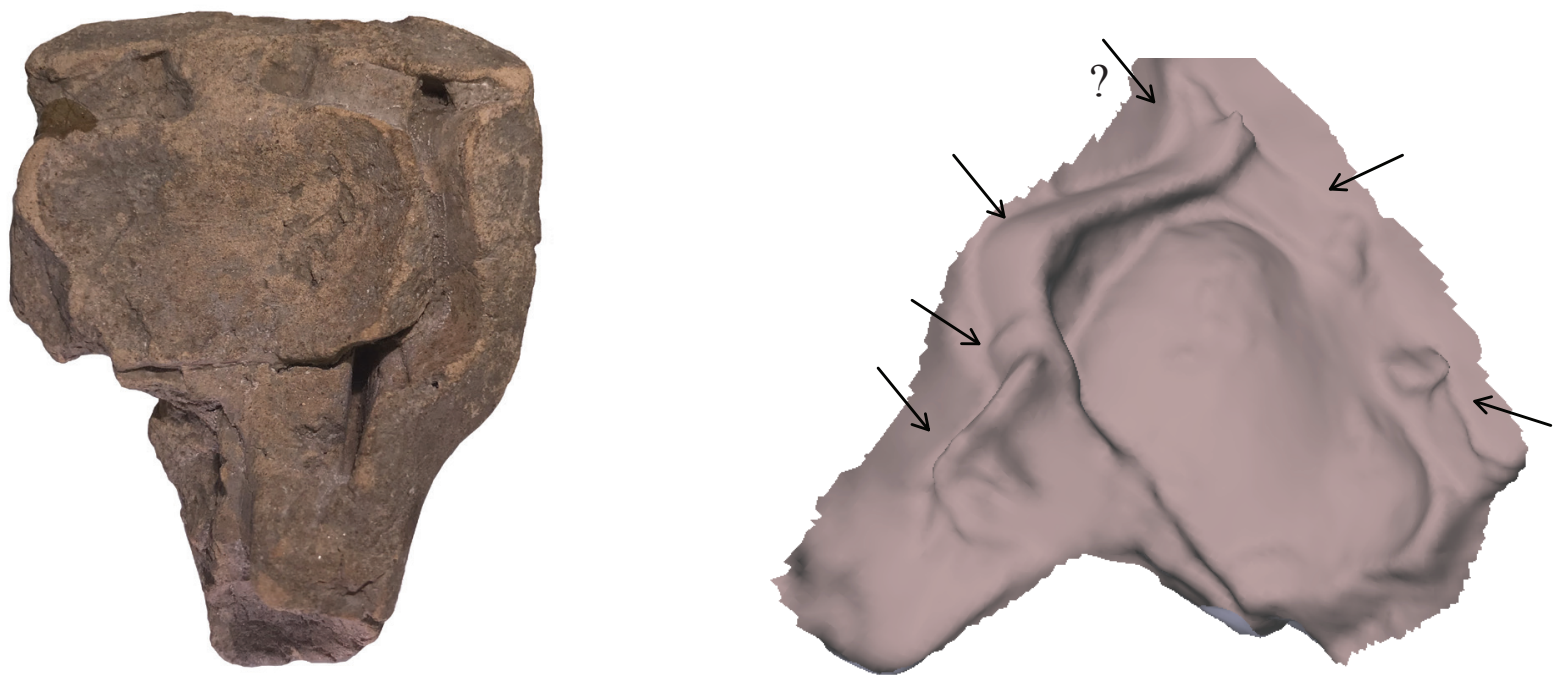

Fig. 2. Cat. 2. clay mould and the positive model (made by A. Bödőcs).

The fibula of the last mould (Cat. 3) cannot be easily identified. It is one half of a two-piece clay mould similarly to the above-mentioned pieces and it suggests that with this mould only a single fibula was cast at a time. This fibula can also be seen in profile, its hook and catchplate are well recognizable. According to the imprint, the hook of the fibula was pierced, therefore a semi-finished product was used as a pattern.

17 MerCZI 2011, 31-32.

18 Berecz 1987, 251, 265-266.

19 It is summarized by M. Merczi (Merczi 2011, 32). Further pieces from Fejér County: SÁRó 2011, Kat. 233, Kat. 241, Kat. 244, Kat. 253, Kat. 284, XXVIII. tábla 6, XXIX. tábla 1, XXX. tábla 1, 5; Further pieces from Pest County: SÁró 2011, Kat. 281, XXVIII. tábla 7; Merczi 2012, Kat. 81-82, 7. kép 3, 10; Merczi 2017, Kat. 68-69, 4. tábla 1, 8. tábla 11. Further pieces from Tolna County: SÁró 2011, Kat. 276, XXIX. tábla 5; SÁró 2014a, 310, Cat. 18, Fig. 2.5; SÁró 2014b, 195-197, 199, Kat. 74-75, Kat. 82, Kat. 84, Kat. 96, 9. tábla 3, 6-7, 10. tábla 6-7.

20 Schmid 2010, 109-110, Taf. 20. 175-176, Taf. 21. 183, 186, 188, Taf. 42. A11. The fibula from Karlsdorf was dated to the second half of the 2nd century AD (Heymans 1997, 354-355, Taf. 8. 78, 80-81, Taf. 9. 87-90). 
The characteristics of the fibula can be seen on the model (Fig. 3):

- according to the hook, the fibula had an internal chord and a spring-construction,

- the catchplate is narrow, therefore it could either have been a very narrow, rectangular and lateral catchplate or a perpendicular catchplate with an openwork surface,

- based on the form, the thickness and the profile, the fibula was probably a plate fibula.

The question is, what type of plate fibula could have been made with this mould? In my opinion, two possibilities can be accepted which I would like to present in the following part of the paper.
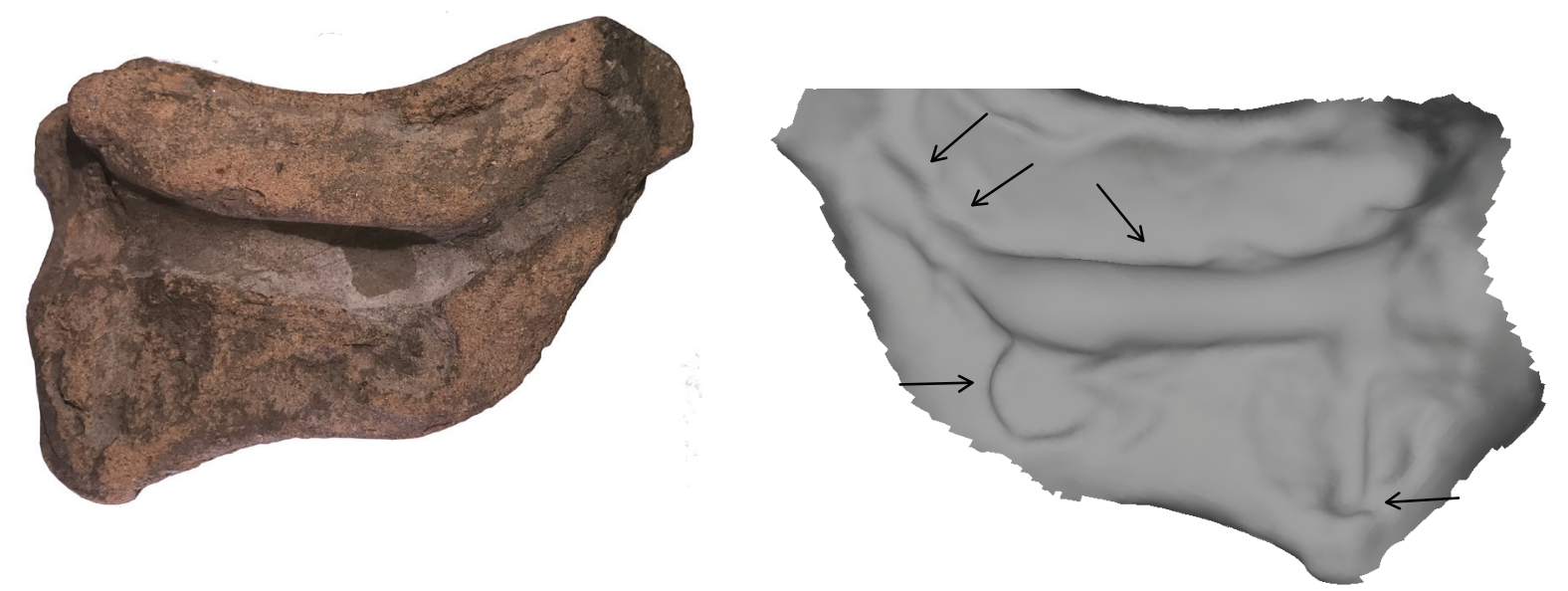

Fig. 3. Cat. 3. clay mould and the positive model (made by A. Bödőcs).

According to the first theory, the mould holds the imprint of a horn-shaped fibula. Hornshaped fibulae (Patek F = Bojović $29.1=$ Cociş 23b) ${ }^{21}$ are known in different forms. One of the main characteristics is the number of the horns, which can vary between one and three. If the mould from Brigetio has been used for making horn-shaped fibulae, it could be a single horn instead of a double or triple.

The details of the positive model can be compared to the pieces known from the archaeological record. Only one horn-shaped fibula is known from Brigetio and no further piece can be mentioned from Komárom-Esztergom County. The exact find spot of the fibula is unknown, the only data being that it was found in Szőny (App. 3). The form of the bow, the hook and the catchplate of the horn-shaped fibula from Brigetio are similar to the model's picture, the hook turns inward and the lateral catchplate is very narrow. However some differences can also be observed. In the picture of the positive model a small element of the bow can be seen above the pin construction. These parts can be a cross-rib and a thickening end of the bow. According to our actual knowledge, horn-shaped fibulae have a unique form and the existence of a fibula with these elements is conceivable but unproven.

Horn-shaped fibulae are rare in Pannonia but one piece can be mentioned from the military camp of Carnuntum. ${ }^{22}$ The type is more frequent in the southern provinces. The one-horn fibula variation can be mentioned from the cemetery of Devnya (Marcianopolis) ${ }^{23}$ and Vimi- 
nacium, ${ }^{24}$ but it is also known from Turkey ${ }^{25}$ and from several military camps in Dacia. ${ }^{26}$ With a more complex form (Cociş 23c), horn-shaped fibula is known from Potaissa, ${ }^{27}$ Viminacium-Stig. ${ }^{28}$ The other, three-horn fibula variation is known from Ritopek ${ }^{29}$ and Singidunum. ${ }^{30}$

According to their form, the question arises whether they had been special costume accessories. The horn shape suggests that they had been used by men, probably soldiers. Based on the minimal amount of information, this theory could not be proven yet. However, it should be mentioned that a man had been buried with a horn-shaped fibula and a military belt in Grave No. G1-507 at Viminacium. ${ }^{31}$

Fibulae in the shape of tools and personal articles (skeumorphic fibulae) were dated to the 2 nd-3rd centuries AD by E. Patek. ${ }^{32}$ Based on the new finds, some information can be added. The horn-shaped fibula from Grave No. 23 at Marcianopolis was found with a coin of Hadrian (119 $\mathrm{AD})^{33}$ and the horn-shaped fibulae from Dacia can be dated from the 170s to the beginning of the 3 rd century $\mathrm{AD} .{ }^{34}$

Finally, the second theory about the type should be discussed. Based on the main characteristics, the imprint of the Cat. 3 mould can also belong to a bird shaped fibula.

Bird shaped fibulae were produced in very different forms. E. Patek categorized the bird shaped fibulae from Pannonia in 10 types. Several kinds of birds could be recognized, namely duck, goose, pigeon, rooster and legionary eagle. She discussed the pieces with or without enamel together. ${ }^{35}$ More recently, bird shaped fibulae
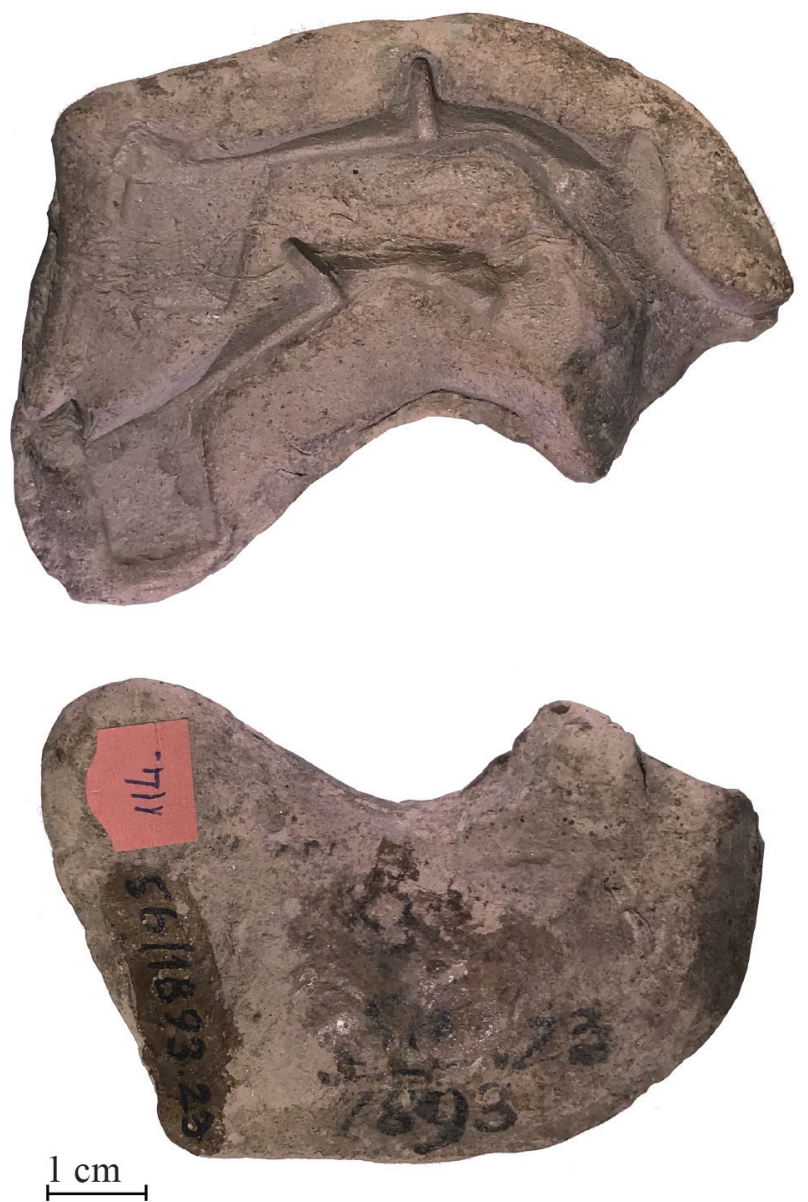

Fig. 4. Cat. 1. clay mould.

24 ReDŽıć 2007, 51, T. 23. 265. = PetKović 2010, 221, Nr. 1100.

25 Hattatt 2000, 394, Fig. 217. 1149.

26 Bologa: Cocış 2004, 206, Pl. CIII. 1465. Porolissum: Cocış 2004, 206, Pl. CIII. 1464.

27 Cociş 2004, 206, Pl. CIII. 1466.

28 REDŽIĆ - Jovičić 2010, 55, T. II. 21.

29 Petković 2010, 184, Nr. 976, T. XXXII. 5.

30 Bojović 1983, 140-141, T. XXXI. 301.

31 PetKović 2010, 221.

32 Patek 1942, 50.

33 REDŽIĆ 2007, 51.

34 COCIŞ 2004, 121.

35 PateK 1942, 52; Patek 1942, 220, T. XX. 1 = Sellye 1939, T. XIII. 14; PAtek 1942, 220, T. XX. 2. = Sellye 1939, T. XIII. 17; Patek 1942, 220, T. XX. 3-4; Patek 1942, 220, T. XX. 9. = Sellye 1939, T. XIII. 29; Patek 1942, T. XX. 10; Patek 1942, 221, T. XX. 7-8; Patek 1942, 221, T. XXI. 19. = Sellye 1939, T. XIII. 15; Patek 1942, 221-222, T. XXI. 20; PAtek 1942, 222, T. XXI. 21; PAtek 1942, 222, T. XXI. 22-23. 


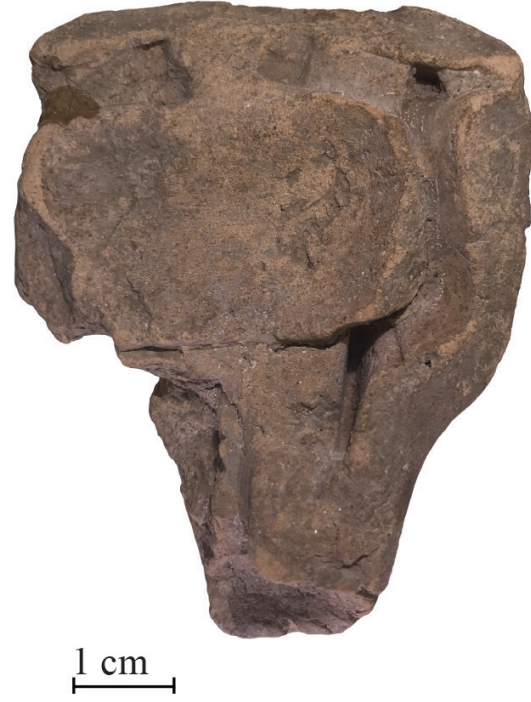

Fig. 5. Cat. 2. clay mould.

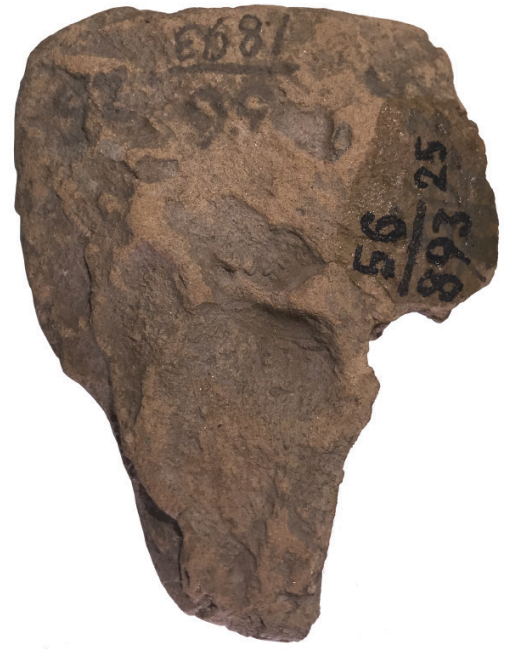

The characteristics of the fibula model from Brigetio can be compared with actual fibulae from the archaeological records. It appears that the variant Winter IIIa $1^{39}$ has similar elements (Fig. 11.1). A spring pin-construction and a perpendicular catchplate are typical for this type. The bird's body is thick, the tail-feather curves upwards, body and tail divided by a small rib. Winter IIIa1 fibulae are known from Flavia Solva ${ }^{40}$ for example, but none had been found in Brigetio and Komárom-Esztergom County yet. Only other types are known from Brigetio and its closer vicinity so the distribution map of the bird shaped fibulae is of no use regarding the question of identification (Fig. 11.2-5).

According to E. Patek, animal shaped fibulae were certainly used in the 2nd century AD. ${ }^{41}$ The variant Winter IIIa1 can be dated to the second third of the 2nd century and the end of the 3rd century AD. ${ }^{42}$

\section{Summary}

Of the known casting moulds from Brigetio, six were more or less certainly used for the production of fibulae. During my research, I tried a new analytical method, namely the clay moulds were examined by a 3D scanner. The examination of the fibula variants was based on the scanned pictures and the models. In conclusion of the research it can be stated that the above-mentioned method is quite useful. The imprints of the intact pieces and the imprints with a recognizable part of a fibula type can be investigated, however, unfortunately the fragmented or featureless imprints cannot be interpreted.

Berecz 2008, 151, IIC/1a1; Berecz 2008, 151, IIC/1a2; Berecz 2008, 152, IIC/1a3; BereCZ 2008, 152, IIC/1a4; Berecz 2008, 152, IIC/1b; Berecz 2008, 152-153, IIC/1c; Berecz 2008, 153, IIC/1d1; BereCZ 2008, 153, IIC/1d2; Berecz 2008, 153, IIC/1e; BerecZ 2008,159, IID/1; BerecZ 2008, 160, IID/5.

37 MatouscheK - Nowak 1986, 130-142, 210-212.

38 Variante Ia1, Ia2, Ib, IIa1, IIa2, IIb1, IIb2, IIc, IIIa1, IIIa2, IIIb1, IIIb2, IIIc, IV (WINTER 1986, 338-369).

39 WiNTER 1986, 339, 347-348, 365.

40 Winter 1986, 347-348, Nr. 31-32. = Kropf - NowAK 2000, 154, Nr. 394-395.

41 PATEK 1942, 51.

42 Kropf - NowAK 2000, 154. 
The main aim of my paper was the presentation of the fibula variants produced in the investigated clay moulds, related to which three objects were discussed in detail. Strongly profiled fibulae, knee fibulae and skeumorph or bird shaped plate fibulae were made in these moulds. According to their form and construction, the fibula variants could be defined, their distribution and dating were summarized. The Almgren $84=$ Merczi 2014/3, the Merczi 2011/B/2 and the Bojović 29.1 = Cociş 23b fibulae can be dated to the 2nd century and the beginning of the 3rd century AD, while the Winter IIIa1 fibulae were in use from the last third of the 2nd century to the end of the 3rd century. The two bow fibula types were manufactured as mass products and they are also known in great numbers from the environment of Brigetio as well as from other parts of Pannonia and further provinces. The horn shaped and bird shaped fibulae are more unique. Unfortunately, only a few or none of them were found around Brigetio, thus their distribution could not provide decisive evidence regarding the question of the Cat. 3 imprint.

As mentioned in the beginning, further objects also refer to the fibula manufacture of Brigetio, such as semi-finished and waste products. In most cases their variants are well recognizable so their distribution and dating are analyzable. These fibulae will be the subject of a next study.

\section{Catalogue $^{43}$}

1. Piece mould (Fig. 4).

It is a half of a two-piece mould without a trace of burning. Material: clay. Color: light yellow. Imprint: It is the complete profile of two bow fibulae under each other.

Size: L.: 73 mm, W.: 49-29 mm, Th.: $12 \mathrm{~mm}$

Finding place: Brigetio/Szőny

Coll.: HNM Inv.no.: 56.1893.23.

Lit.: Kovrig 1937, 91, T. XXVII. 1a; B. BóNIs 1986, Abb. 1. 1; Sey 2013a, Kat. 53; Merczi 2014, 18.

2. Piece mould (Fig. 5).

It is a half of a two-piece mould without a trace of burning. Material: clay. Color: light yellow. Imprint: Originally, it was the complete profile of two bow fibulae in mirror image but the left one is now fragmented.

Size: L.: 63 mm, W.: 49-19 mm, Th.: 19-13 mm

Finding place: Brigetio/Szőny

Coll.: HNM Inv.no.: 56.1893.25.

Lit.: Kovrig 1937, 90, T. XXVI. 4; Sey 2013a, 49, Kat. 55.

3. Piece mould (Fig. 6).

It is a half of a two-piece mould without a trace of burning. Material: clay. Color: orangish-light yellow. Imprint: It is the complete profile of one fibula. Size: L.: $65 \mathrm{~mm}$, W.: 39-18 mm, Th.: $16 \mathrm{~mm}$ Finding place: Brigetio/Szőny
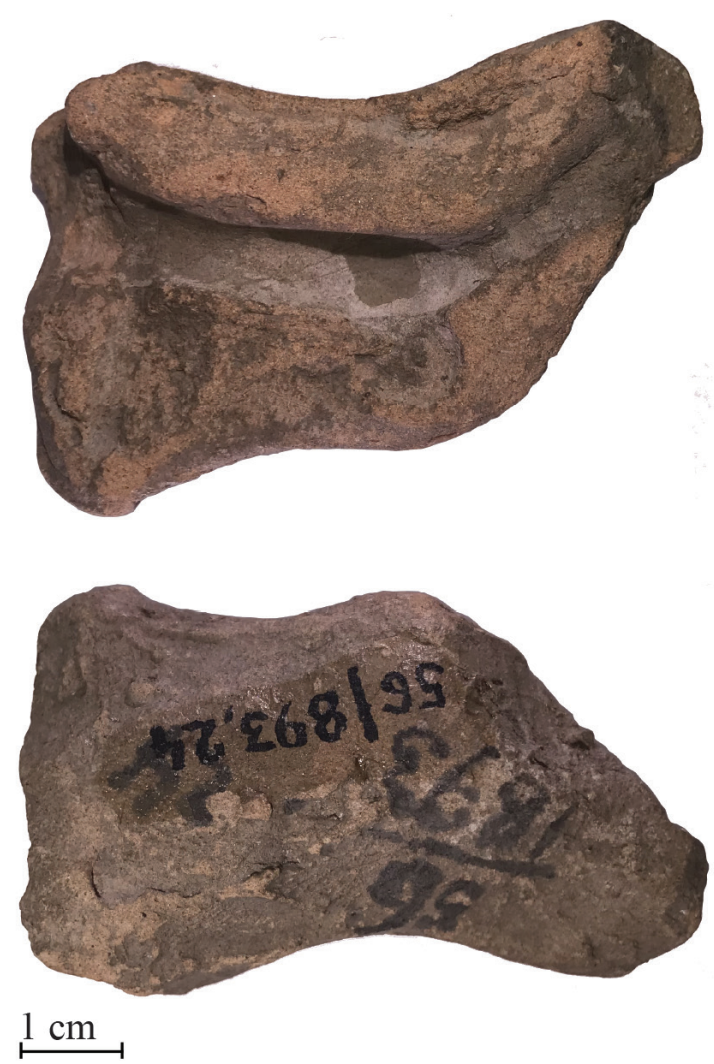

Fig. 6. Cat. 3. clay mould.

43 Abbreviation: L.: length; W.: width; Th.: thickness; Coll.: collection; Inv.no.: inventory number; Lit.: literature; KGyM: Komáromi Klapka György Museum (Komárom); KDM: Kuny Domokos Museum (Tata); HNM: Hungarian National Museum (Budapest); TBM: Tatabányai Museum (Tatabánya). 
Coll.: HNM Inv.no.: 56.1893.24.

Lit.: Kovrig 1937, T. XXVII. 1e; SEy 2013a, Kat. 54.

4. Piece mould.

It is a half of a two-piece mould. Fragmented, burnt. Material: clay. Color: light-yellow. Imprint: two elongated objects, probably fibulae.

Size: L.: $73 \mathrm{~mm}$, W.: $51 \mathrm{~mm}$, Th.: 19-6 mm

Finding place: Brigetio/Szőny-Vásártér, municipium

Coll.: KGyM Inv.no.: 2011.L14.084.157.

Lit.: SEY 2013a, Kat. 74; SEY 2015, 225, Cat. 11.

5. Piece mould.

It is a half of a two-piece mould. Fragmented, burnt. Material: clay. Color: light-yellow. Imprint: trace of an object (fibula?).

Size: L.: $32 \mathrm{~mm}$, W.: $20 \mathrm{~mm}$, Th.: $17 \mathrm{~mm}$

Finding place: Brigetio/Szőny-Dunapart, canabae

Coll.: KGyM Inv.no.: 2015.8.665.4.

Lit.: SEy 2018, Cat. 113, Fig. IV. 3.

6. Piece mould.

It is a half of a two-piece mould. Fragmented, burnt. Material: clay. Color: grey. Imprint: trace of an object (fibula?).

Size: L.: $52 \mathrm{~mm}$, W.: $35 \mathrm{~mm}$, Th.: $11 \mathrm{~mm}$

Finding place: Brigetio/Szőny-Dunapart, canabae

Coll.: KGyM Inv.no.: 2015.8.607.3.

Lit.: SEY 2018, Cat. 114.

\section{References}

AlMgRen, O. 1923: Studien über nordeuropäischen Fibelformen der ersten nachchristlichen fahrhunderte mit Berücksichtigung der provinzialrömischen und südrussischen Formen. Leipzig.

BARTus, D. 2011: Roman Figural Bronzes from Brigetio: Preliminary Notes. Anodos. Studies of the Ancient World 10, 17-28.

BARTus, D. 2014a: Terrakotta öntőforma ólom Mercurius szobrok készítéséhez Brigetióból. In: BALÁzs, P. (szerk.): FIRKÁK III. Fiatal Római Koros Kutatók III. konferenciakötete, 2008. november 25-27, Szombathely, Savaria Museum - 2012. november 15-17, Szombathely, Iseum Savariense. Szombathely, 161-168.

BARTus, D. 2014b: A new Roman terracotta mould for lead Mercurius figurines from Brigetio. Anodos. Studies of the Ancient World 11, 29-36.

BARTus, D. 2015: Bronzistenek. Római kori figurális bronzplasztika Brigetióban. Acta Archaeologica Brigetionensia I/8. Komárom.

Bartus, D. - Borhy, L. - Delbó, G. - Dévai, K. - Kis, Z. - Nagy, A. - SÁró, Cs. - Sey, N. - SzÁmadó, E. VIDA, I. 2015a: Jelentés a Komárom-Szőny, Vásártéren 2013-ban folytatott régészeti feltárások eredményeiről (Bericht über die Ergebnisse der in Brigetio (FO: Komárom/Szőny, Vásártér) im Jahre 2013 geführten archäologischen Ausgrabungen). Kuny Domokos Múzeum Közleményei 21, 7-78.

Bartus, D. - Borhy, L. - Delbó, G. - SzÁmadó, E. 2014: A new Roman bath in the canabae of Brigetio. Short report on the excavation at the site Szőny-Dunapart in 2014. Dissertationes Archaeologicae $3 / 2,437-449$.

Bartus, D. - Borhy, L. - Sey, N. - SzÁmadó, E. 2018: Excavations in Brigetio (2012-2016). In: Borhy, L.DÉvaI, K.-TANKó, K. (eds): Celto - Gallo - Roman. Studies of the MTA-ELTE Research Group for Interdisciplinary Archaeology. Paris, 63-81.

Bartus, D. - Borhy, L. - SzÁmadó, E. 2015b: Short report on the excavations in Brigetio in 2015. Civil town, canabae and legionary fortress. Dissertationes Archaeologicae 3/3, 245-262. doi: 10.17204/ dissarch.2015.245 
Berecz, K. 1987: Adatok a térdfibulák Pannoniai történetéhez. Unpublished MA-thesis. ELTE Eötvös Loránd University. Budapest.

BERECZ, K. 2008: Aucissa és emailos fibulák Pannoniában és a szomszédos Barbaricumban. Unpublished PhD-thesis. ELTE Eötvös Loránd University. Budapest.

Bojović, D. 1983: Rimske fibule Singidunuma. Beograd.

B. BóNIs, É. 1986: Das Militärhandwerk der Legio I Adiutrix in Brigetio. In: Unz, C. (ed.): Studien zu den Militärgrenzen Roms III. 13. Internationaler Limeskongreß Aalen 1983. Vorträge. Stuttgart, 301-307.

Cocış, S. 2004: Fibulele din Dacia Romană. The brooches from roman Dacia. Cluj-Napoca.

Csirke, O. - K. Palágyi, S. 2005: Római kori ékszerek és viseleti tárgyak a veszprémi Laczkó Dezső Múzeum gyüjteményéből (Römerzeitliche Schmuck- und Trachtgegenstände des Museums „Laczkó Dezs”̋" von Veszprém). Veszprém.

FARKA, C. 1977: 1977 eingelangte Fundberichte. Römische Kaiserzeit. Bruckneudorf. Fundberichte aus Österreich 16, 394.

FARKA, C. 1988: Fundberichte 1988. Römische Kaiserzeit. Petronell. Fundberichte aus Österreich 27, 313-314.

Farka, C. - Jungwirth, J. 1984: 1984 eingelangte Fundberichte. Römische Kaiserzeit. Petronell. Fundberichte aus Österreich 23, 296.

Farka, C. - Jungwirth, J. 1989: Fundberichte 1989. Römische Kaiserzeit. Petronell. Fundberichte aus Österreich 28, 232-233.

FARKA, C. - KROPF, W. 1986: 1985-1986 eingelangte Fundberichte. Römische Kaiserzeit. Strebersdorf. Fundberichte aus Österreich 24-25, 278.

FARKA, C. - MatouscheK, J. 1987: Fundberichte 1987. Römische Kaiserzeit. Pöttsching. Fundberichte aus Österreich 26, 232.

Farka, C. - Melzer, G. 1979a: 1979 eingelangte Fundberichte. Römische Kaiserzeit. Mannersdorf am Leithagebirge. Fundberichte aus Österreich 18, 454.

Farka, C. - Melzer, G. 1979b: 1979 eingelangte Fundberichte. Römische Kaiserzeit. Sommerein. Fundberichte aus Österreich 18, 464.

Farka, C. - Stelzer, A. 1983: 1983 eingelangte Fundberichte. Römische Kaiserzeit. Deutsch Jahrndorf. Fundberichte aus Österreich 22, 275.

FARKA, C. - Winter, H. 1980: 1980 eingelangte Fundberichte. Römische Kaiserzeit. Kaisersteinbruch. Fundberichte aus Österreich 19, 485-486.

GenčEva, E. 2004: Les fibules romaines de Bulgarie de la fin du I'r s. av. f.-C. à la fin du VIe s. ap. f.-C.

Grausam, H. - Nowak, H. 1988: Fundberichte 1988. Römische Kaiserzeit. Edelstal. Fundberichte aus Österreich 27, 293.

Grausam, C. - Grausam, H. - NowaK, H. 1992a: Fundchronik. Römische Kaiserzeit. Hollern. Fundberichte aus Österreich 31, 493.

Grausam, C. - Grausam, H. - Nowak, H. 1992b: Fundchronik. Römische Kaiserzeit. Zurndorf. Fundberichte aus Österreich 31, 474-475.

Hattatt, R. 2000: A Visual Catalogue of Richard Hattatt's Ancient Brooches. Oxford. doi: 10.2307/j.ctvh1drxn

Heymans, H. 1997: Die Fibeln aus dem römerzeitlichen Vicus von Kalsdorf bei Graz. Fundberichte aus Österreich 36, 325-374.

Kovrig, I. 1937: A császárkori fibulák fó formái Pannoniában (Die Haupttypen der kaiserzeitlichen Fibeln in Pannonien). Dissertationes Pannonicae II/4, Budapest.

Krenn-Leeb, A. - Jandrasits, H. 1994: Fundchronik. Römische Kaiserzeit. Petronell. Fundberichte aus Österreich 33, 579. 
Kropf, W. - Nowak, H. 2000: Fibeln von Flavia Solva aus Privatbesitz. Römisches Österreich 21-22, Wien. LACKNER, A. 1999: Fundchronik. Römische Kaiserzeit. Neckenmarkt. Fundberichte aus Österreich 38, 822.

LamiovÁ-Schmiedlová, M. 1961: Spony z doby rímskej na Slovensku (Die Fibeln der römerzeit in der Slowakei). Študijné zvesti AÚSAV 5. Nitra.

Matouscheк, J. 1980: 1980 eingelangte Fundberichte. Römische Kaiserzeit. Jois. Fundberichte aus Österreich $19,485$.

MatouscheK, J. 1990: Fundberichte 1990. Römische Kaiserzeit. Sankt Margarethen. Fundberichte aus Österreich 29, 229.

Matouscheк, J. - Nowak, H. 1986: Unpublizierte Tierfibeln und Fibeln mit thermiomorphen Gestaltungselementen aus österreichischen Privatsammlungen. Römisches Osterreich 13-14, 101-222.

Merczi, M. 2011: Térdfibulák Komárom-Esztergom megyéből (Provinzialrömische Kniefibeln aus Komitat Komárom-Esztergom). Komárom-Esztergom Megyei Múzeumok Közleményei 17, 7-80.

MerczI, M. 2012: A Budaörs-Kamaraerdei-dűlőben feltárt római vicus fibulái. In: ОттомÁNyi K. (szerk.): Római vicus Budaörsön. Régészeti tanulmányok. Budapest, 455-528.

Merczi, M. 2014: Támlap nélküli egygombos, erősprofilú fibulák Északkelet-Pannoniából (Kräftig profilierte Fibeln ohne Stützplatte aus Nordost-Pannonien). Kuny Domokos Múzeum Közleményei 20, 7-31.

MercZI, M. 2017: Római kori fibulák Perbálról és Zsámbékról (Roman fibulae from Perbál and Zsámbék). Studia Comitatensia 35, 71-119.

NowaK, H. 1988: Fundberichte 1988. Römische Kaiserzeit. Zurndorf. Fundberichte aus Österreich 27, 302-303.

PAтEK, E. 1942: A pannoniai fibulatípusok elterjedése és eredete (Verbreitung und Herkunft der römischen Fibeltypen in Pannonien). Dissertationes Pannonicae sII/19, Budapest.

A. PÁL, G. 2000: Madár alakú fibula Tatabánya-Bánhida, Erőműtó lelőhelyről (A bird-shaped fibel [founded Tatabánya-Bánhida, Erőműtó]). Komárom-Esztergom Megyei Múzeumok Közleményei 7, 289-291.

Petković, S. 2010: Rimske fibule u Srbiji od I do V veka N. E. (Römische Fibeln in Serbien von 1. bis 5. Jh. nach Chr.). Archäologisches Institut Monographie 50, Beograd.

REDžIć, S. 2007: Nalazi rimskih fibula na nekropolama Viminacijuma (Finding of Roman brooches in the cemeteries of Viminacium). Arheologija i prirodne nakue/Archaeology and science 4, Beograd.

REDžić, S. - Jovičıć, M. 2010: Unpublished finds of roman fibulas from the territory of Viminacium. Arheologija i prirodne nauke/Archaeology and Science 6, 49-60.

SÁRó, Cs. 2011: A pannoniai közép-dunai limes kora császárkori fibulatípusai. Unpublished MA-thesis. ELTE Eötvös Loránd University. Budapest.

SÁró, Cs. 2014a: Roman brooches from Paks-Gyapa-Rosti-puszta. Dissertationes Archaeologicae 3/2, 299-319.

SÁRó, Cs. 2014b: Kora császárkori fibulák a Wosinsky Mór Megyei Múzeum gyűjteményéből (Fibeln von der Frühkaiserzeit aus der Sammlung des Komitatsmuseums Mór Wosinsky). A Wosinsky Mór Múzeum Évkönyve 36, 159-221.

Schmid, S. 2010: Die römischen Fibeln aus Wien. Monografien der Stadtarchäologie Wien 6. Wien.

Sellye, I. 1939: Császárkori emailmunkák Pannoniából (Les bronzes émaillés de la Pannonie romaine). Dissertationes Pannonicae Ser. 2. No. 8. Budapest.

SEY, N. 2013a: A pannoniai római kori bronzmüvesség mühelykérdései. Unpublished PhD thesis. ELTE Eötvös Loránd University. Budapest.

SEY, N. 2013b: Questions of bronze workshops in Roman Pannonia. Dissertaiones Archaeologicae 3/1, 251-258. 
SEY, N. 2015: Roman bronze workshop in the civil town of Brigetio. In: BorHy, L.-DÉvaI, K.-TANKó, K. (eds): Studia Archaeologica Nicolae Szabó LXXV Annos Nato dedicata. Budapest, 225-236.

SEY, N. 2018: Bronze and bone workshop in the territory of the legionary fortress and canabae of Brigetio. In: Borhy, L.-DÉvaI, K.-TANkó, K. (eds): Celto - Gallo - Roman. Studies of the MTA-ELTE Research Group for Interdisciplinary Archaeology. Paris, 223-242.

SEYFried, V. 1983: 1983 eingelangte Fundberichte. Römische Kaiserzeit. Schützen am Gebirge. Fundberichte aus Österreich 22, 277.

STUndNER, J. 2006: Ausgewählte Fibeln des 1. und 2. Jahrhunderts aus Aelium Cetium und seinem Umland. Römisches Österreich 29, 135-170.

Szabó, K. 1990: Gazdaság - Bronzipar. In: Mócsy, A.-Fitz, J. (szerk.): Pannonia régészeti kézikönyve. Budapest, 130-150.

Winter, H. 1986: Römische Vogelfibeln von österreichischen Fundstellen aus Privatbesitz. Römisches Österreich 13-14, 323-369. 

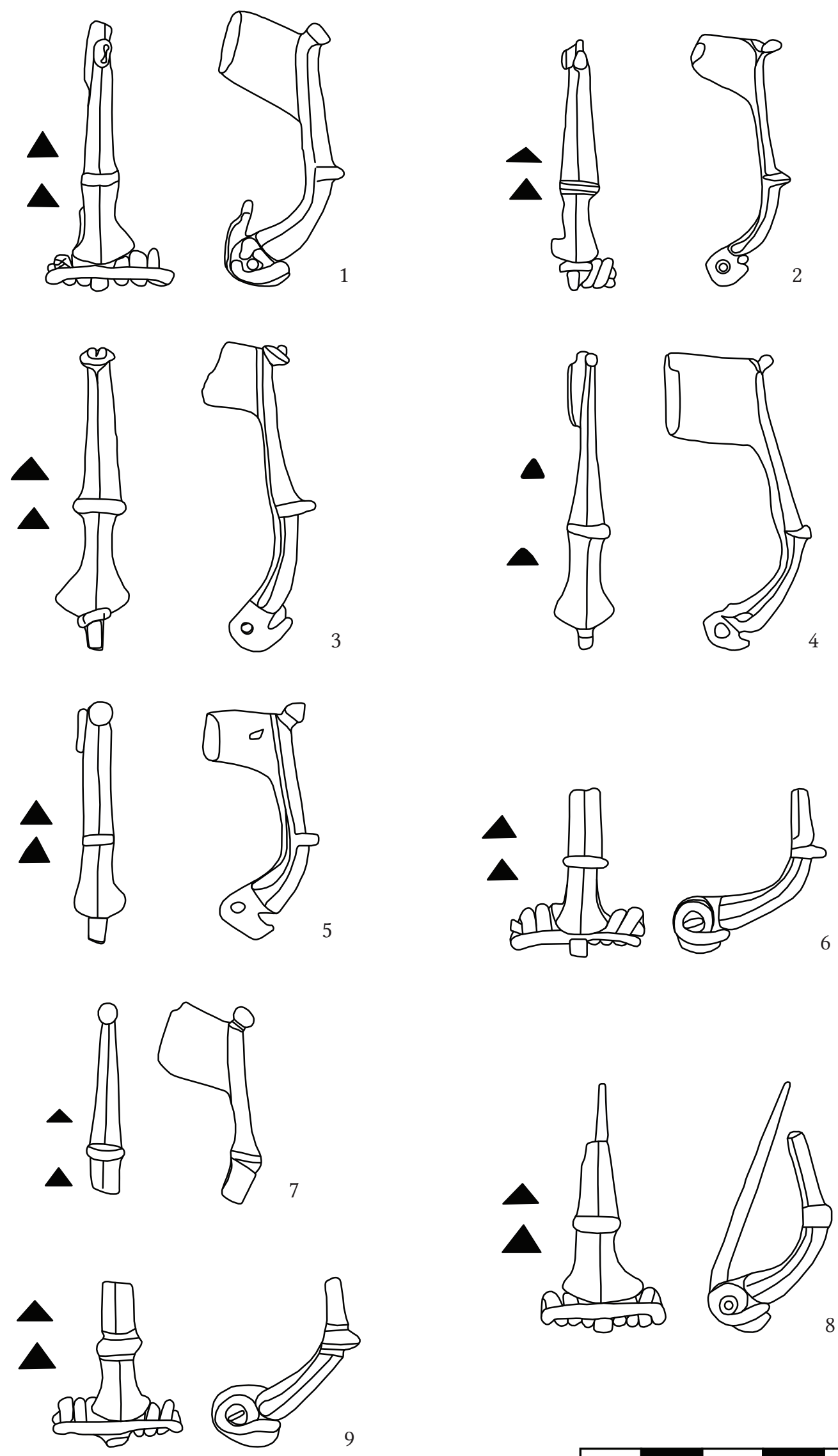

Fig. 7. 1 - App. 1.5, 2 - App. 1.4, 3 - App. 1.3, 4 - App. 1.7, 5 - App. 1.24/1, 6 - App. 1.17, 7 - App. 1.24/2, 8 - App. 1.23, 9 - App. 1.22 . 

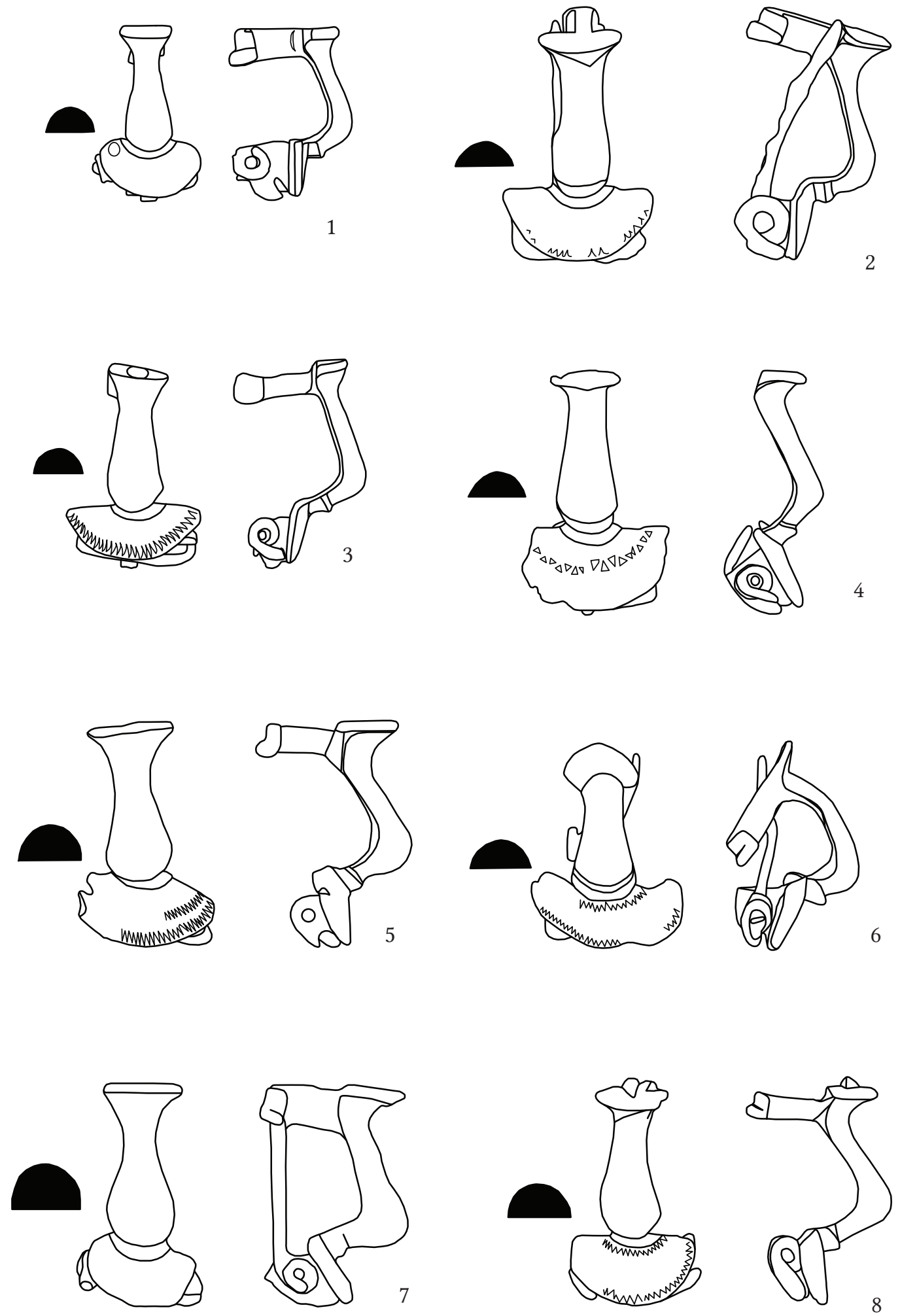

Fig. 8. 1 - App. 2.1, 2 - App. 2.2, 3 - App. 2.3, 4 - App. 2.4, 5 - App. 2.5, 6 - App. 2.6, 7 - App. 2.7, 8- App. 2.8. 

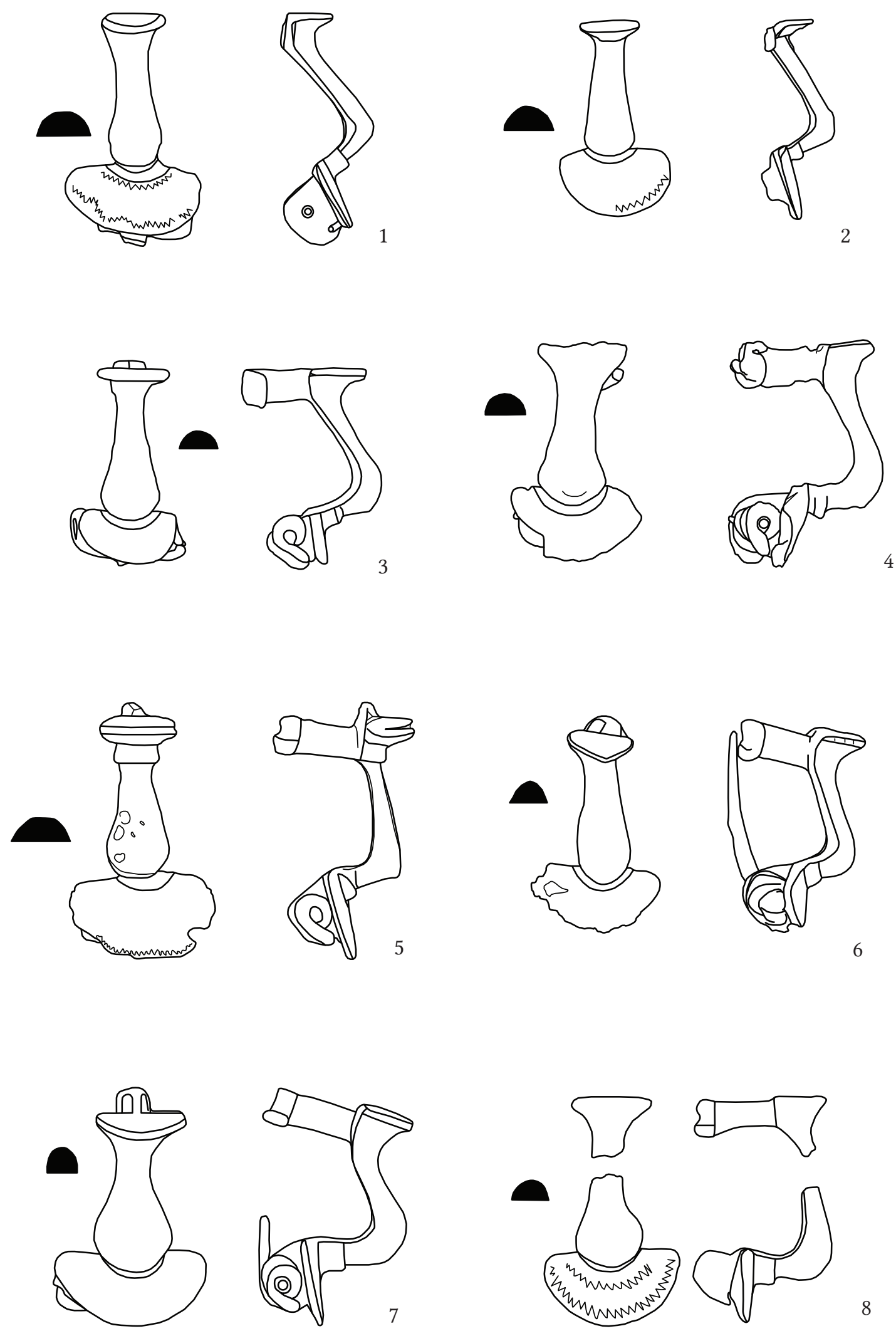

8

Fig. 9.1 - App. 2.9, 2 - App. 2.10, 3 - App. 2.13, 4 - App. 2.15, 5 - App. 2.16, 6 - App. 2.19, 7 - App. 2.22, 8 - App. 2.23. 
Csilla SÁRó
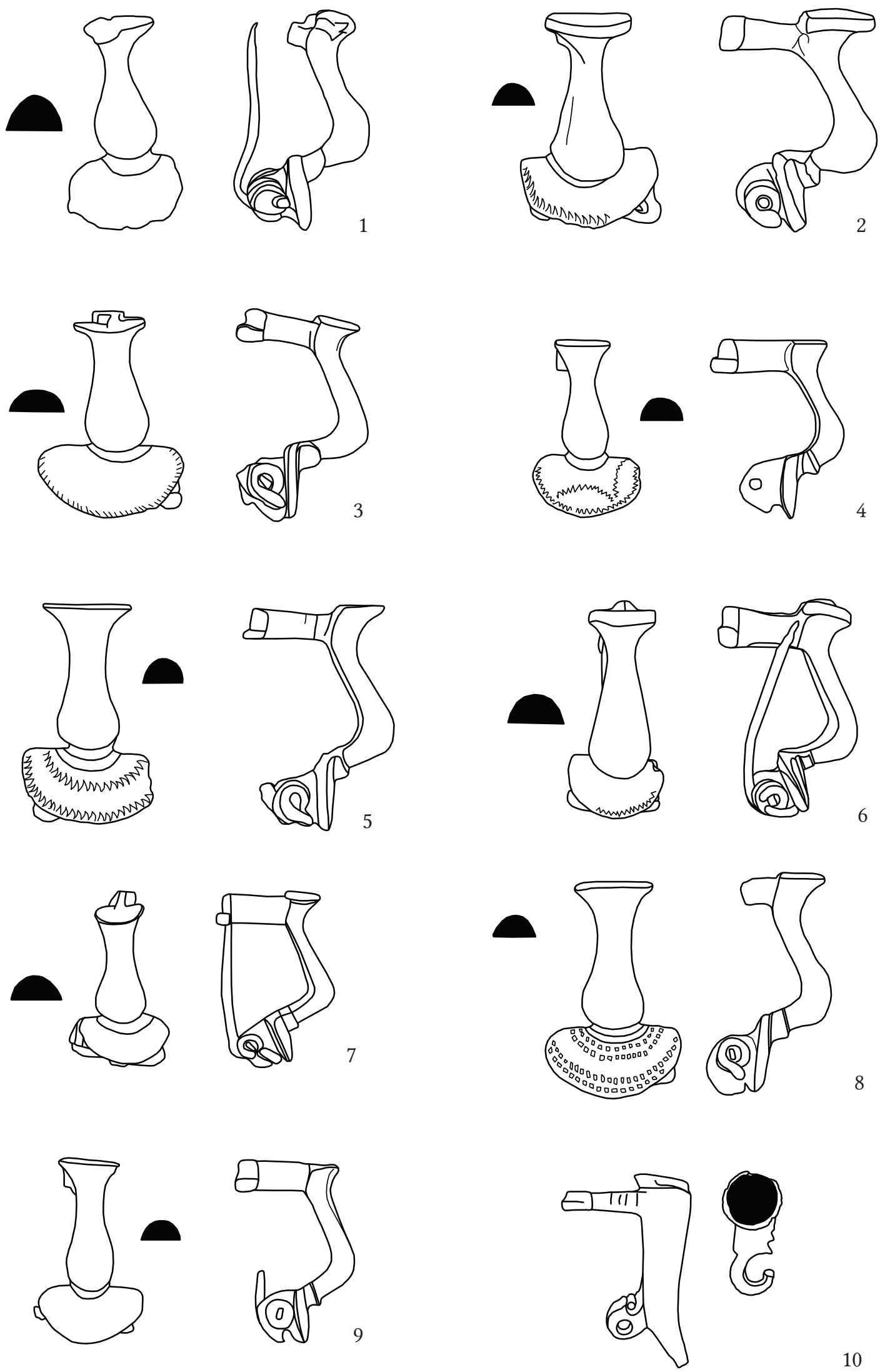

6

8

Fig. 10. 1 - App. 2.24, 2 - App. 2.25, 3 - App. 2.26, 4 - App. 2.27, 5 - App. 2.28, 6 - App. 2.36/1, 7 - App. 2.36/2, 8 - App. 2.38, 9 - App. 2.43, 10 - App. 3.1.

132 

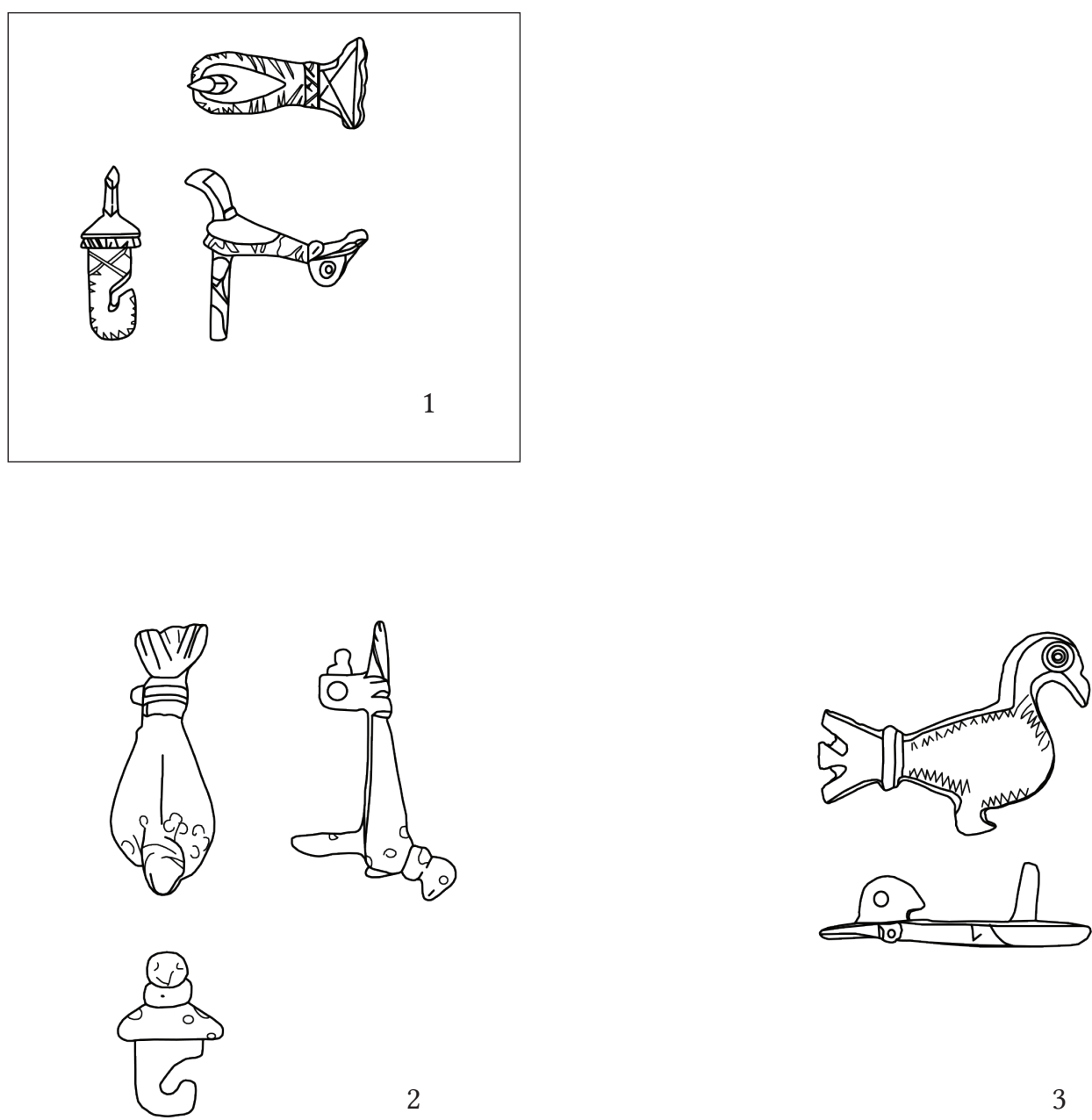

3
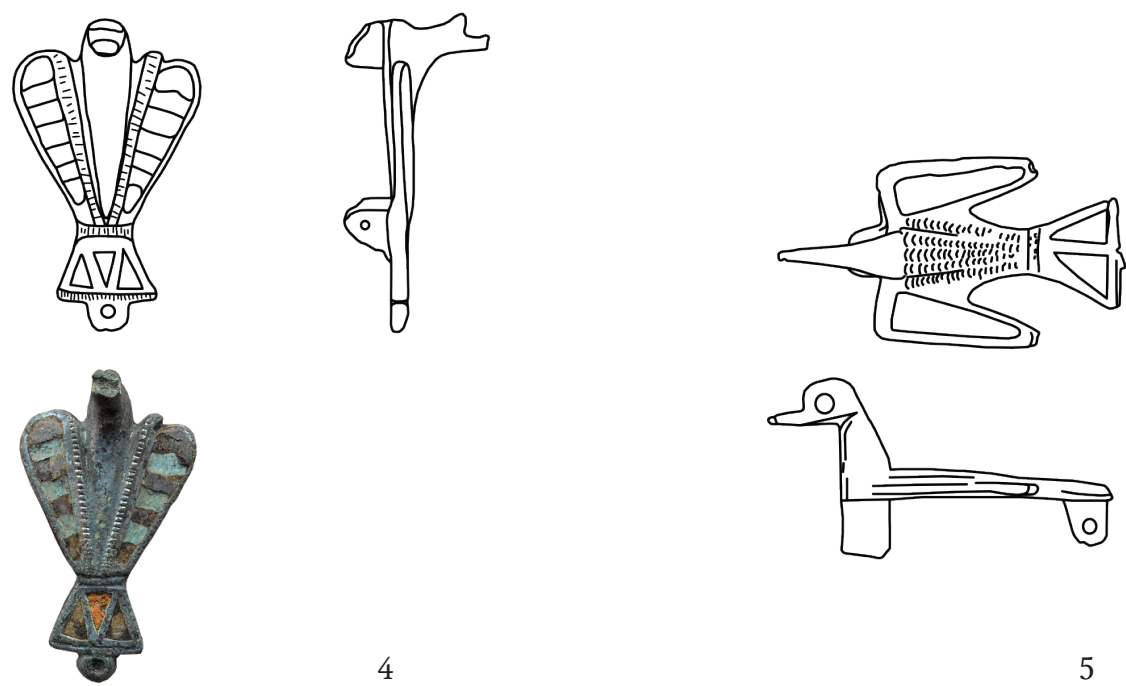

4

5

Fig. 11.1 - Winter IIIa1 fibula (Winter 1986, Nr. 31), 2 - Winter IIIb1 fibula from Brigetio (App. 4.1), 3 Winter IIc fibula from Brigetio (App. 4.2), 4 - Berecz 2008/IIC/1a1 fibula from Tarján (App. 4.3), Berecz 2008/IIC/1a2 fibula from Tatabánya-Bánhida (App. 4.4). 


\section{Appendix}

\section{Evidence of the manufacture: Cat. 1. mould}

Type: strongly profiled fibula: Almgren $84=$ Merczi 2014/3

Fibulae from Brigetio and Komárom-Esztergom County:

1. Szőny/Brigetio-Vásártér Lit.: BARTus et al. 2015a, 43, Kat. 1, 25. tábla 1.

2. Szőny/Brigetio-Vásártér Lit.: BARTus et al. 2015a, 43, Kat. 2, 25. tábla 2.

3. Szőny/Brigetio (Fig. 7.3)

Coll.: KDM Inv.no.: K-1441

Size: L.: $50 \mathrm{~mm}, \mathrm{~W}_{\text {bow }}: 11 \mathrm{~mm}$

Main characteristics: Copper-base alloy, undecorated, the end-knob is multi-part (truncated cone shaped and cylindrical knob).

Lit.: -

4. Szőny/Brigetio (Fig. 7.2)

Coll.: KDM Inv.no.: K-1443

Size: L.: $41 \mathrm{~mm}, \mathrm{~W}_{\text {pin-construction }}$ : $9 \mathrm{~mm}, \mathrm{~W}_{\text {bow }}: 7 \mathrm{~mm}$

Main characteristics: Copper-base alloy, undecorated, the end-knob is one-part (drop shaped knob).

Lit.: PATEK 1942, 174, T. IV. 12/Nr. 13.

5. Szőny/Brigetio (Fig. 7.1)

Coll.: KDM Inv.no.: K-1446/1

Size: L.: $43 \mathrm{~mm}, \mathrm{~W}_{\text {pin-construction }}: 21 \mathrm{~mm}, \mathrm{~W}_{\text {bow }_{\text {ow }}}: 11 \mathrm{~mm}$

Main characteristics: Copper-base alloy, undecorated, the end-knob is one-part (round knob).

Lit.: -

6. Szőny/Brigetio

Lit.: MerCZi 2014, 14, Kat. 35, 4. tábla 8.

7. Szőny/Brigetio (Fig. 7.4)

Coll.: HNM Inv.no.: 152.1885.370.

Size: L.: $48 \mathrm{~mm}, \mathrm{~W}_{\text {bow }}: 10 \mathrm{~mm}$

Main characteristics: Copper-base alloy, undecorated, the end-knob is one-part (round knob).

Lit.: -

8. Szőny/Brigetio-Olajtartályok

Lit.: Merczi 2014, 23, Kat. 29, 4. tábla 2.

9. Szőny/Brigetio or Iža/Leányvár/Celemantia

Lit.: LAmiovÁ-Schmiedlová 1961, 62, T. XIX. 7.

10. Ácsteszér

Lit.: Csirke - K. PALÁgyi 2005, 19, Kat. 3.2.

11. Bajna-Józsahegy and Papföldi dűlő, 2 pieces

Lit.: Merczi 2014, 11, Kat. 18, 2. tábla 9, Kat. 23, 3. tábla 5.

12. Bajót-Domonkoshegy

Lit.: Merczi 2014, 14, Kat. 36, 4. tábla 9.

13. Bajót-Péliföldszentkereszt, 3 pieces

Lit.: Merczi 2014, 11-12, Kat. 19-21, 3. tábla 1-3.

14. Epöl-Kőkúti-dűlő, 2 pieces

Lit.: Merczi 2014, 12-14, Kat. 26, 3. tábla 8, Kat. 33, 4. tábla 6.

15. Epöl-Kőkúti-dűlő and Palkóvölgyi-dűlő

Lit.: Merczi 2014, 12, Kat. 22, 3. tábla 4.

16. Area of Esztergom-Hideglelőskereszt, 3 pieces

Lit.: Merczi 2014, 12-14, Kat. 24, 3. tábla 6, Kat. 27, 3. tábla 9, Kat. 34, 4. tábla 7. 
17. Héreg-Temetőhegy (Fig. 7.6)

Coll.: TBM

Size: L.: $23 \mathrm{~mm}, \mathrm{~W}_{\text {pin-construction }}: 23 \mathrm{~mm}, \mathrm{~W}_{\text {bow }}: 12 \mathrm{~mm}$

Main characteristics: Copper-base alloy, undecorated.

Lit.: -

18. Nyergesújfalu-Gunyhóalji-dűlő

Lit.: Merczi 2014, 12, Kat. 25, 3. tábla 7.

19. Sárisáp-Dedinsko Lit.: Merczi 2014, 13, Kat. 28, 4. tábla 1.

20. Tarján-Tornyópuszta Lit.: Merczi 2014, 23, Kat. 30, 4. tábla 3.

21. Vértesszőlős Lit.: Merczi 2014, 23, Kat. 32, 4. tábla 5.

22. Vértesszőlős-Felső-Rét föld (Fig. 7.9)

Coll.: TBM

Size: $\mathrm{L} .: 27 \mathrm{~mm}, \mathrm{~W}_{\text {pin-construction }}: 21 \mathrm{~mm}, \mathrm{~W}_{\text {bow: }}: 10 \mathrm{~mm}$ Main characteristics: Copper-base alloy, undecorated. Lit.: -

23. Vértesszőlős, road Nr. 1. (Fig. 7.8)

Coll.: TBM

Size: L.: $41 \mathrm{~mm}, \mathrm{~W}_{\text {pin-construction }}: 20 \mathrm{~mm}, \mathrm{~W}_{\text {bow: }}: 13 \mathrm{~mm}$

Main characteristics: Copper-base alloy, undecorated.

Lit.: -

24. Vértestolna-Buncsú-kút, 2 pieces (Fig. 7.5, Fig. 7.7)

Coll.: TBM

Size: L.: $39 \mathrm{~mm}, \mathrm{~W}_{\text {bow }}: 8 \mathrm{~mm}, \mathrm{~L} .: 32 \mathrm{~mm}, \mathrm{~W}_{\text {bow }}: 5 \mathrm{~mm}$

Main characteristics: Copper-base alloy, undecorated, the end-knob is one-part (cone shaped knob). Copper-base alloy, undecorated, the end-knob is one-part (round knob).

Lit.: -

\section{Evidence of the manufacture: Cat. 2. mould}

Type: knee fibula: Merczi 2011/B/2.

\section{Fibulae from Brigetio and Komárom-Esztergom County:}

1. Szőny/Brigetio-Vásártér (Fig. 8.1)

Coll.: KGyM Inv.no.: 2011.001.2.

Size: $\mathrm{L}_{\text {.: }} 28 \mathrm{~mm}, \mathrm{~W}_{\text {pin-construction }}: 17 \mathrm{~mm}, \mathrm{~W}_{\text {headplate }}: 16 \mathrm{~mm}$

Main characteristics: Copper-base alloy, undecorated, the bow ends in a rim.

Lit.: -

2. Szőny/Brigetio-Vásártér (Fig. 8.2)

Coll.: KGyM Inv.no.: 2007.K41.120.1.

Size: L.: $41 \mathrm{~mm}, \mathrm{~W}_{\text {headplate }}: 24 \mathrm{~mm}$

Main characteristics: Copper-base alloy, the headplate is decorated with chased zigzag pattern, the bow ends in a rim.

Lit.: -

3. Szőny/Brigetio-Vásártér (Fig. 8.3)

Coll.: KGyM Inv.no.: 2008.H19.088.35.

Size: L.: $33 \mathrm{~mm}, \mathrm{~W}_{\text {pin-construction }}: 19 \mathrm{~mm}, \mathrm{~W}_{\text {headplate }}: 22 \mathrm{~mm}$

Main characteristics: Copper-base alloy, the headplate is decorated with chased wolf-tooth pattern, the bow ends in a rim.

Lit.: - 
4. Szőny/Brigetio-Dunapart (Fig. 8.4)

Coll.: KGyM Inv.no.: 2014.6.1.103.

Size: L.: $38 \mathrm{~mm}, \mathrm{~W}_{\text {pin-construction }}: 18 \mathrm{~mm}, \mathrm{~W}_{\text {headplate }}: 23 \mathrm{~mm}$

Main characteristics: Copper-base alloy, the headplate is decorated with chased triangles, the bow has a plain ending.

Lit.: -

5. Szőny/Brigetio-Dunapart (Fig. 8.5)

Coll.: KGyM Inv.no.: 2014.6.385.257.

Size: L.: $36 \mathrm{~mm}, \mathrm{~W}_{\text {headplate }}: 22 \mathrm{~mm}$

Main characteristics: Copper-base alloy, the headplate is decorated with chased wolf-tooth pattern, the bow ends in a small rim.

Lit.: -

6. Szőny/Brigetio-Dunapart (Fig. 8.6)

Coll.: KGyM Inv.no.: 2014.6.1.104.

Size: L.: $32 \mathrm{~mm}, \mathrm{~W}_{\text {pin-construction }}: 20 \mathrm{~mm}, \mathrm{~W}_{\text {headplate }}: 24 \mathrm{~mm}$

Main characteristics: Copper-base alloy, the headplate is decorated with chased wolf-tooth pattern, the bow has a plain ending.

Lit.: -

7. Szőny/Brigetio-Dunapart (Fig. 8.7)

Coll.: KGyM Inv.no.: 2017.4.1953.5.

Size: $\mathrm{L} .: 35 \mathrm{~mm}, \mathrm{~W}_{\text {pin-construction }}: 21 \mathrm{~mm}, \mathrm{~W}_{\text {'headplate }}: 18 \mathrm{~mm}$

Main characteristics: Copper-base alloy, undecorated, the bow ends in a rim.

Lit.: -

8. Szőny/Brigetio-Dunapart (Fig. 8.8)

Coll.: KGyM

Size: $\mathrm{L}_{\mathrm{s}}: 36 \mathrm{~mm}, \mathrm{~W}_{\text {pin-construction }}: 20 \mathrm{~mm}, \mathrm{~W}_{\text {headplate }}: 20 \mathrm{~mm}$

Main characteristics: Copper-base alloy, the headplate is decorated with chased zigzag pattern, the bow ends in a rim and a triangular knob.

Lit.: -

9. Szőny/Brigetio-Dunapart (Fig. 9.1)

Coll.: KGyM

Size: L.: $37 \mathrm{~mm}, \mathrm{~W}_{\text {'headplate }}: 22 \mathrm{~mm}$

Main characteristics: Copper-base alloy, the headplate is decorated with chased zigzag pattern, the bow ends in a rim.

Lit.: -

10. Szőny/Brigetio-Dunapart (Fig. 9.2)

Coll.: KGyM

Size: $\mathrm{L} .: 31 \mathrm{~mm}, \mathrm{~W}_{\text {headplate }}: 18 \mathrm{~mm}$

Main characteristics: Copper-base alloy, the headplate is decorated with chased zigzag pattern, the bow has a plain ending.

Lit.: -

11. Szőny/Brigetio-Bélapuszta

Lit.: Merczi 2011, 12, Kat. 43, 5. tábla 1.

12. Szőny/Brigetio-castrum

Lit.: Merczi 2011, 11, Kat. 36, 4. tábla 3.

13. Szőny/Brigetio-Kurucdomb (1954) (Fig. 9.3)

Coll.: MNM Inv.no.: 54.57.1.

Size: L.: $32 \mathrm{~mm}, \mathrm{~W}_{\text {pin-construction }}: 19 \mathrm{~mm}$

Main characteristics: Copper-base alloy, undecorated, the bow ends in a rim.

Lit.: -

14. Szőny/Brigetio-Olajtartályok

Lit.: Merczi 2011, 11-12, Kat. 38, 4. tábla 5. 
15. Szőny/Brigetio-Gerhát cemetery, excavation of A. Radnóti (1946) (Fig. 9.4)

Coll.: HNM Inv.no.: 19.1952.6.

Size: L.: $36 \mathrm{~mm}, \mathrm{~W}_{\text {}_{\text {headplate }}}: 22 \mathrm{~mm}$

Main characteristics: Copper-base alloy, undecorated, the bow has a plain ending.

Lit.: BERECZ 1987, 166, 340, Kat. 83.

16. Szőny/Brigetio-Járóka cemetery (1929), grave Nr. 93 (Fig. 9.5)

Coll.: HNM Inv.no.: 2.1931.171.

Size: L.: $42 \mathrm{~mm}, \mathrm{~W}_{\text {headplate }}: 24 \mathrm{~mm}$

Main characteristics: Copper-base alloy, the headplate is decorated with chased zigzag pattern, the bow has a multi-part ending (rim, double knob, small knob).

Lit.: -

17. Szőny/Brigetio-Sörház udvar, plain inhumation burial

Lit.: Merczi 2011, 12, Kat. 39, 4. tábla 6.

18. Szőny/Brigetio, land of J. Szalai, plain inhumation burial

Lit.: Merczi 2011, 13, Kat. 58, 6. tábla 8.

19. Szőny/Brigetio, excavation of L. Barkóczi (1957), grave Nr. 84. (Fig. 9.6)

Coll.: HNM Inv.no.: 62.36.189.

Size: L.: $34 \mathrm{~mm}, \mathrm{~W}_{\text {headplate }}: 21 \mathrm{~mm}$

Main characteristics: Copper-base alloy, undecorated headplate, the bow ends in a decorated rim.

Lit.: -

20. Szőny/Brigetio

Lit.: Merczi 2011, 11, Kat. 29, 3. tábla 6.

21. Szőny/Brigetio

Lit.: Merczi 2011, 11, Kat. 35, 4. tábla 2.

22. Szőny/Brigetio, grave (Fig. 9.7)

Coll.: KDM Inv.no.: 72.39.16b

Size: L.: $36 \mathrm{~mm}, \mathrm{~W}_{\text {-headplate }}: 24 \mathrm{~mm}$

Main characteristics: Copper-base alloy, undecorated, the bow ends in a rim.

Lit.: -

23. Szőny/Brigetio (Fig. 9.8)

Coll.: HNM Inv.no.: 152.1885.376.

Size: L.: $25 \mathrm{~mm}, \mathrm{~L}_{2}: 10 \mathrm{~mm}, \mathrm{~W}_{\text {theadplate }}: 22 \mathrm{~mm}$

Main characteristics: Copper-base alloy, the headplate is decorated with chased zigzag pattern, the bow has a plain ending.

Lit.: -

24. Szőny/Brigetio (Fig. 10.1)

Coll.: HNM Inv.no.: 141.1888.56.

Size: L.: $36 \mathrm{~mm}, \mathrm{~W}_{\text {'headplate }}: 19 \mathrm{~mm}$

Main characteristics: Copper-base alloy, undecorated, the bow has a plain ending.

Lit.: Patek 1942, 231, T. XXII. 12. típus/Nr. 90; BerecZ 1987, 173, 352, Kat. 106.

25. Szőny/Brigetio (Fig. 10.2)

Coll.: HNM Inv.no.: 27.1894.7.

Size: L.: $37 \mathrm{~mm}, \mathrm{~W}_{\text {headplate }}: 23 \mathrm{~mm}$

Main characteristics: Copper-base alloy, the headplate is decorated with chased wolf-tooth pattern, the bow ends in a rim.

Lit.: BERECZ 1987, 178-179, 354, Kat. 127.

26. Szőny/Brigetio (Fig. 10.3)

Coll.: HNM Inv.no.: 79.1902.2.

Size: L.: $34 \mathrm{~mm}, \mathrm{~W}_{\text {'headplate }}: 24 \mathrm{~mm}$

Main characteristics: Copper-base alloy, the headplate is decorated with chased lines, the bow ends in a small rim.

Lit.: - 
27. Szőny/Brigetio (Fig. 10.4)

Coll.: HNM Inv.no.: 63.22.36.

Size: $\mathrm{L} .: 29 \mathrm{~mm}, \mathrm{~W}_{\text {'headplate }}: 18 \mathrm{~mm}$

Main characteristics: Copper-base alloy, the headplate is decorated with chased zigzag pattern, the bow ends in a rim.

Lit.: BERECZ 1987, 171-172, 352, Kat. 102.

28. Szőny/Brigetio (Fig. 10.5)

Coll.: HNM Inv.no.: 63.22.42.

Size: L.: $36 \mathrm{~mm}, \mathrm{~W}_{\text {headplate }}: 21 \mathrm{~mm}$

Main characteristics: Copper-base alloy, the headplate is decorated with chased zigzag pattern, the bow has a plain ending.

Lit.: Berecz 1987, 174, 353, Kat. 115.

29. Bajna-Józsa-hegy - Papföldi-dűlő

Lit.: Merczi 2011, 12, Kat. 41, 4. tábla 8.

30. Bajna-Sárás

Lit.: MerCZI 2011, 13, Kat. 55, 6. tábla 5.

31. Bajót-Domonkos-hegy, 4 pieces

Lit.: Merczi 2011, 11-13, Kat. 30, 3. tábla 7, Kat. 37, 4. tábla 4, Kat. 48-49, 5. tábla 6-7.

32. Bajót-Péliföldszentkereszt, 2 pieces

Lit.: Merczi 2011, 12-13, Kat. 44, 5. tábla 2, Kat. 51, 6. tábla 1.

33. Epöl-Kőkúti-dűlő

Lit.: Merczi 2011, 12, Kat. 40, 4. tábla 7.

34. Epöl-TSz-farm - Palkóvölgyi-dűlő

Lit.: Merczi 2011, 12, Kat. 42, 4. tábla 9.

35. Area of Esztergom-Hideglelőskereszt

Lit.: Merczi 2011, 13, Kat. 50, 5. tábla 8.

36. Környe, 2 pieces (Fig. 10.6; Fig. 10.7)

Coll.: TBM Inv.no.: 2018.1.1., 2018.1.3.

Size: L.: $36 \mathrm{~mm}, \mathrm{~W}_{\text {headplate }}: 17 \mathrm{~mm}$, L.: $29 \mathrm{~mm}, \mathrm{~W}_{\text {headplate }}: 15 \mathrm{~mm}$

Main characteristics: Copper-base alloy, the headplate is decorated with chased zigzag pattern, the bow ends in a rim and a triangular knob. Copper-base alloy, undecorated, the bow has a plain ending.

Lit.: -

37. Sárisáp

Lit.: Merczi 2011, 11, Kat. 31, 3. tábla 8.

38. Szomód-Agostyán (Fig. 10.8)

Coll.: HNM Inv.no.: 38.1903.37.

Size: $\mathrm{L} .: 36 \mathrm{~mm}, \mathrm{~W}_{\text {headplate }}: 23 \mathrm{~mm}$

Main characteristics: Copper-base alloy, the headplate is decorated with chased squares, the bow ends in a rim.

Lit.: BERECZ 1987, 182, 355, Kat. 139.

39. Szomor-Anyácsapuszta

Lit.: Merczi 2011, 13, Kat. 57, 6. tábla 7.

40. Vértestolna-Buncsú-kút

Lit.: Merczi 2011, 12, Kat. 46, 5. tábla 4.

41. unknown site/KDM, 7 pieces

Lit.: Merczi 2011, 11, Kat. 32-34, 3. tábla 9-10, 4. tábla 1; Merczi 2011, 12, Kat. 45, 5. tábla 3; Merczi 2011, 13, Kat. 54, 6. tábla 4, Kat. 53, 6. tábla 3, Kat. 56, 6. tábla 6.

42. unknown site/TBM

Coll.: TBM Inv.no.: 2008.12.2.

Lit.: Merczi 2011, 12, Kat. 47, 5. tábla 5. with wrong Inv.no.: TBM 2008.6.3.

43. unknown site - Komárom Esztergom County/MNM (Fig. 10.9) 
Coll.: HNM Inv.no.: 2.1950.263.2.

Size: L.: $30 \mathrm{~mm}$, W.: $18 \mathrm{~mm}, \mathrm{~W}_{\text {'headplate }}: 17 \mathrm{~mm}$

Main characteristics: Copper-base alloy, undecorated, the bow has a plain ending.

Lit.: -

44. unknown site/EBM

Lit.: Merczi 2011, 12, Kat. 52, 6. tábla 2.

\section{Evidence of the manufacture: Cat. 3. mould}

Type: plate fibula

Skeumorph fibula, horn-shaped fibula: Cociş $23 b$

1. Szőny/Brigetio (Fig. 10.10)

Coll.: KDM Inv.no.: K-1508

Size: L.: $32 \mathrm{~mm}, \mathrm{~W}_{\text {bow }}$ : $9-3 \mathrm{~mm}$

Main characteristics: Copper-base alloy, the narrow catchplate is decorated with chased lines.

Lit.: -

Animal-shaped fibula, bird fibula: Winter IIIa1

No pieces are known yet.

\section{Bird shaped fibulae from Brigetio and Komárom-Esztergom County:}

1. Szőny/Brigetio (Fig. 11.2)

Coll.: HNM Inv.no.: 63.22.78.

Size: L.: $33 \mathrm{~mm}, \mathrm{~W}_{\text {bow }}: 12 \mathrm{~mm}$

Main characteristics: Copper-base alloy, plastic representation, hinged-pin, the tail feathers are decorated with chased lines.

Type: Winter IIIb1

Lit.: -

2. Szőny/Brigetio (Fig. 11.3)

Coll.: KDM Inv.no.: K-400

Size: L.: $32 \mathrm{~mm}, \mathrm{~W}_{\text {bow }}: 24 \mathrm{~mm}$

Main characteristics: Copper-base alloy, plane, sprung pin, the body is decorated with chased zigzag pattern, the eye is stamped.

Type: Winter IIc

Lit.: PATEK 1942, 200, T. XX. 3-4/Nr. 1.

3. Tarján (Fig. 11.4)

Coll.: KDM Inv.no.: 2002.1.1.

Size: L.: $33 \mathrm{~mm}, \mathrm{~W}_{\text {bow }}: 19 \mathrm{~mm}$

Main characteristics: Copper-base alloy, white metal covering, plastic representation, hinged-pin, decorated with chased lines and enamel (orange, turquoise, maybe yellow).

Type: Berecz 2008/IIC/1a1

Lit.: -

4. Tatabánya-Bánhida (Fig. 11.5)

Coll.: TBM

Size: L.: $36 \mathrm{~mm}, \mathrm{~W}_{\text {bow }}: 20 \mathrm{~mm}$

Main characteristics: Copper-base alloy, plastic representation, hinged-pin, decorated with chased lines and originally enamel.

Type: Berecz 2008/IIC/1a2

Lit.: A. PÁl 2000, 289-293, 1. tábla; Berecz 2008, 361-362, Kat. C-361. 
